\title{
RDI's Wisdom Way Solar Village Final Report: Includes Utility Bill Analysis of Occupied Homes
}

July 2011

\section{A Case Study}

\author{
Prepared by \\ Steven Winter Associates, Inc \\ For the \\ Consortium for Advanced Residential Buildings (CARB) \\ Steven Winter Associates, Inc \\ 50 Washington Street \\ Norwalk, CT 06854 \\ Tel: (203) 857-0200 / Fax: (203) 852-0741 \\ Contact: Robb Aldrich \\ raldrich@swinter.com
}




\section{Contents}

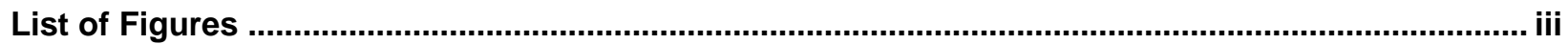

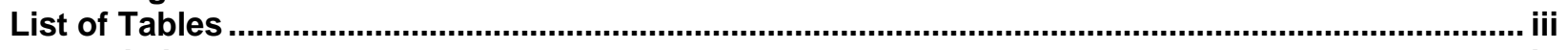

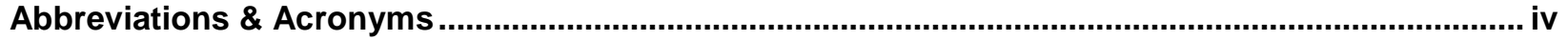

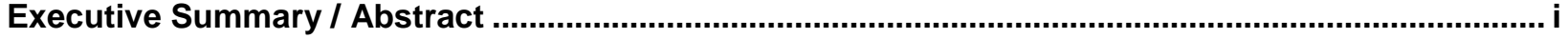

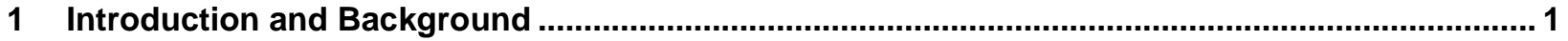

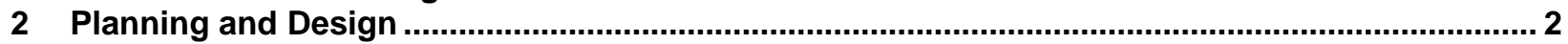

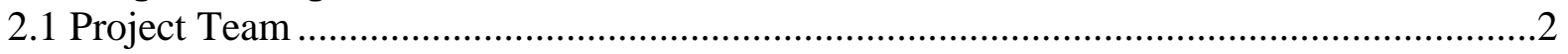

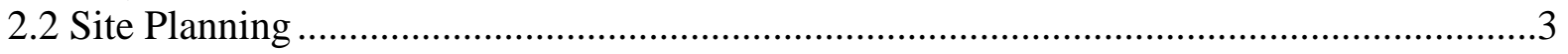

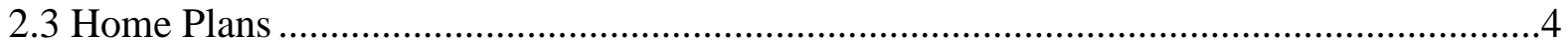

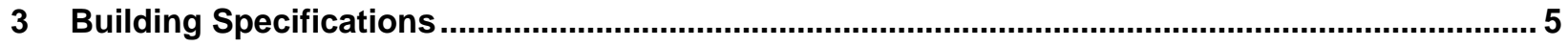

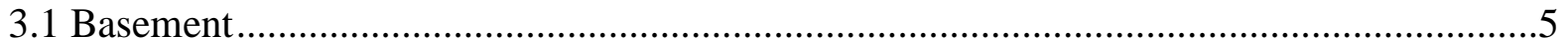

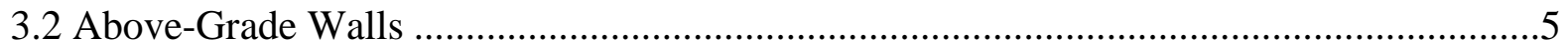

3.3 Attic 8

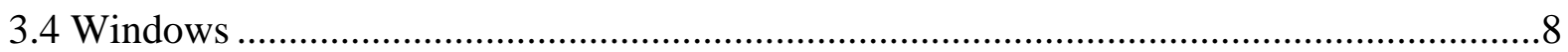

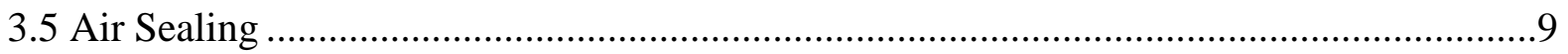

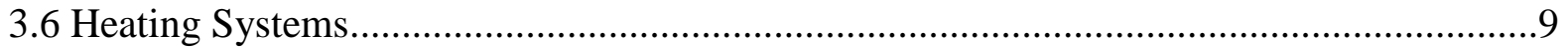

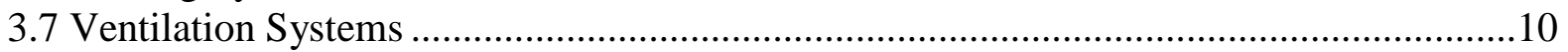

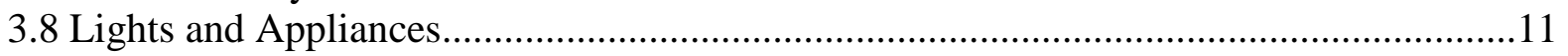

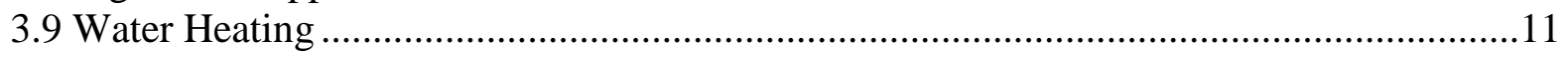

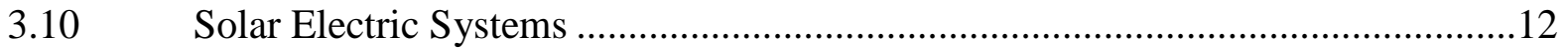

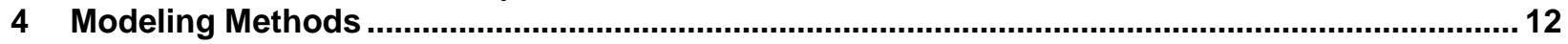

4.1 Building America Benchmark Analyses......................................................................12

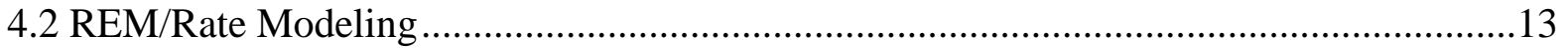

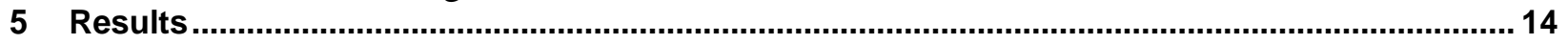

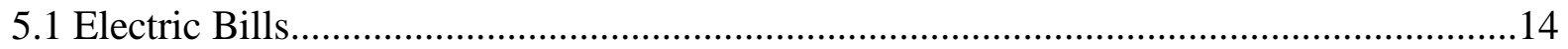

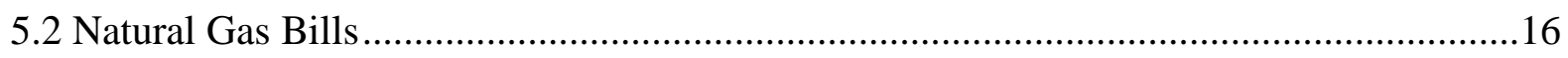

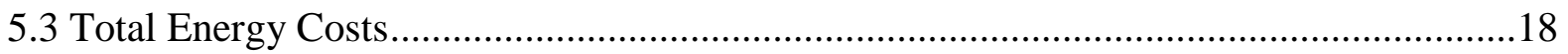

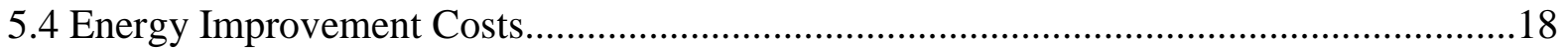

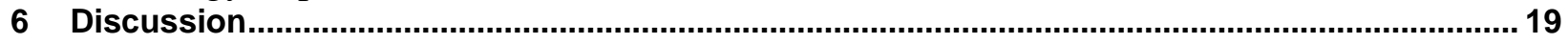

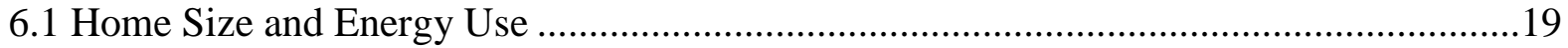

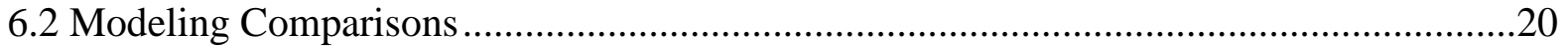

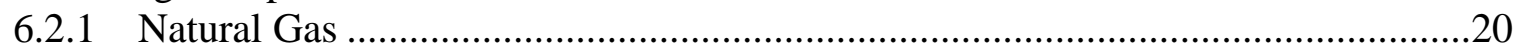

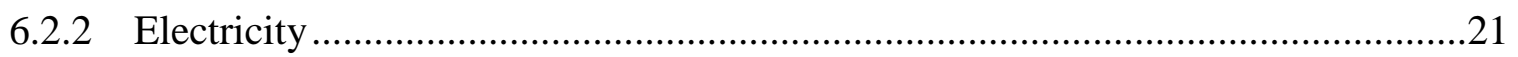

6.2.3 Reasons for Modeling Discrepancies............................................................21

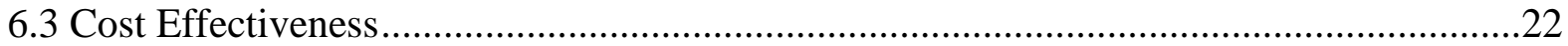

7 Conclusions

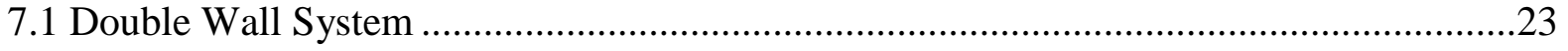

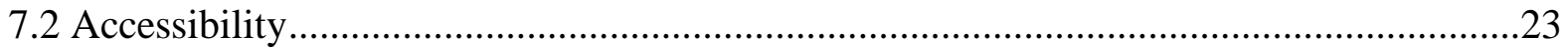

7.3 Siding 24

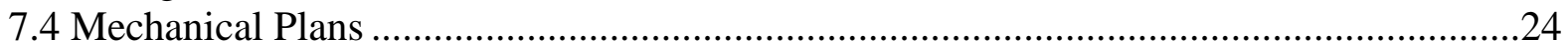

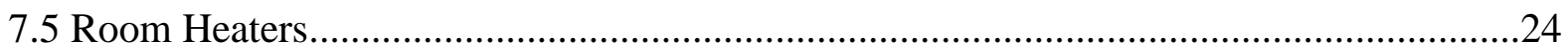

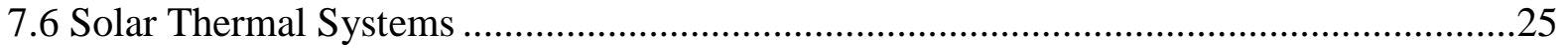

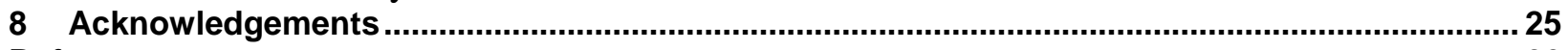

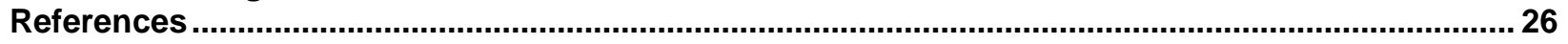

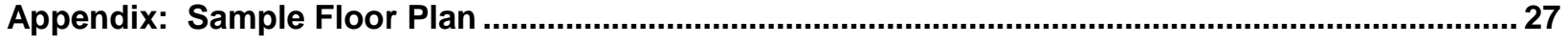




\section{List of Figures}

Figure 1. RDI's prototype "near zero energy" home in Colrain, MA. The home was completed in May, 2007.

Figure 2. One of the completed WWSV duplexes.

Figure 3. Site and landscape plan from Joan S. Rockwell \& Associates. North is directly towards the top of the page.

Figure 4. Ceiling of a basement insulated with blown cellulose ....................................................5

Figure 5. Typical wall section from Austin Design, Inc. Insulation netting was used in stead of rigid insulation between floor joists.

Figure 6. Double walls before and after cellulose insulation. ............................................................ 7

Figure 7. Insulation netting surrounding water heater combustion air and exhaust piping. These small areas were insulated separately to allow access if needed in the future............................. 7

Figure 8. The exhaust fan and simple duct distribution system installed between the first and

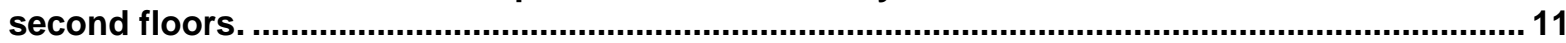

Figure 9. Average, net electricity consumption in WWSV homes from monthly utility bills.

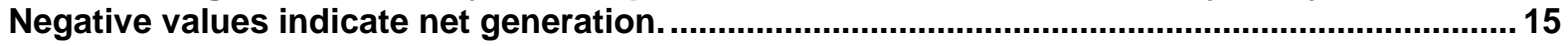

Figure 10. Average natural gas use in 13 occupied WWSV homes.............................................. 16

Figure 11. Average energy use for each home vs. number of bedrooms. There seems to be little,

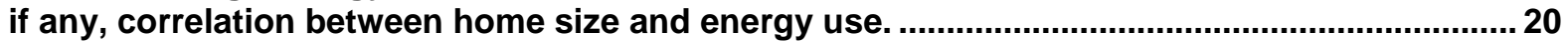

Figure 12. Several completed WWSV homes.

\section{List of Tables}

Table 1. Approximate incremental costs for double-wall construction in a 3-bedroom home at WWSV. Costs are compared to conventional $2 \times 6$ construction with blown cellulose. ............... 8

Table 2. Window properties at Wisdom Way Solar Village........................................................ 9

Table 3. Modeled site energy of 3-bedroom home compared to the baseline home (using Building America Benchmark procedures, 12/20/2007)............................................................................ 12

Table 4. Modeled source energy of 3-bedroom home compared to the baseline home (using Building America Benchmark procedures, 12/20/2007). ............................................................. 13

Table 5. Results of REM/Rate modeling on natural gas use in each home type............................13

Table 6. Results of REM/Rate modeling of electricity use and generation in each home type. ......14

Table 7. Modeled energy costs (REM/Rate). Utility fees include $\$ 9.65$ per month for gas and $\$ 8.53$ per month for electric utilities. Energy rates used here are $\$ 1.50$ per therm and $\$ 0.14$ per $\mathrm{kWh} .14$

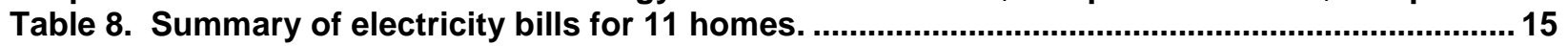

Table 9. 12-month gas consumption for nine occupied WWSV homes. ........................................... 17

Table 10. Summary of gas consumption during heating season. ..................................................... 17

Table 11. Actual, annual energy costs - including utility fees - for eight occupied WWSV homes.18

Table 12. Approximate costs for energy improvements to a 3-bedroom RDI home. Incremental costs are compared to Building America Benchmark specifications........................................ 19

Table 13. Annual natural gas consumption predicted by modeling and actual gas consumed in the homes. *Home 2-2C - which as discussed above had abnormally low gas use - was NOT included in the average below.

Table 14. Modeled and measured electricity consumption in the WWSV homes. The EGUSA values are from the 3-bedroom home. 21

Table 15. Summary of modeled and measured energy costs for a 3-bedroom WWSV home. Electricity costs are $\$ 0.14 / \mathrm{kWh}$ and $\$ 8.63 /$ month. Gas costs are $\$ 1.40 /$ therm and $\$ 9.65 /$ month.22 


\section{Abbreviations \& Acronyms}

AFUE

ASHRAE

BPM

CARB

CFM

DOE

EGUSA

RDI

NREL

PV

SHGC

SWA

WMECO

WWSV
Annual Fuel Utilization Efficiency

American Society of Heating, Refrigeration, and Air Conditioning Engineers

Brushless, Permanent-Magnet (Motor)

Consortium for Advanced Residential Buildings

Cubic Feet per Minute

Department of Energy

EnergyGauge USA

Rural Development, Inc.

National Renewable Energy Laboratory

Photovoltaic

Solar Heat Gain Coefficient

Steven Winter Associates, Inc.

Western Massachusetts Electric Company

Wisdom Way Solar Village 


\section{Executive Summary I Abstract}

In 2010, Rural Development, Inc. (RDI) completed construction of Wisdom Way Solar Village (WWSV), a community of ten duplexes (20 homes) in Greenfield, MA. RDI was committed to very low energy use from the beginning of the design process throughout construction. Key features include:

- Careful site plan so that all homes have solar access (for active and passive);

- Cellulose insulation providing R-40 walls, R-50 ceiling, and R-40 floors;

- Triple-pane windows;

- Airtight construction ( $0.1 \mathrm{CFM}_{50} / \mathrm{ft}^{2}$ enclosure area);

- Solar water heating systems with tankless, gas, auxiliary heaters;

- PV systems (2.8 or $\left.3.4 \mathrm{~kW}_{\mathrm{STC}}\right)$;

- 2-4 bedrooms, $1,100-1,700 \mathrm{ft}^{2}$.

The design heating loads in the homes were so small that each home is heated with a single, sealed-combustion, natural gas room heater. The cost savings from the simple HVAC systems made possible the tremendous investments in the homes' envelopes. CARB monitored temperatures and comfort in several homes during the winter of 2009-2010. In the Spring of 2011, CARB obtained utility bill information from 13 occupied homes.

Because of efficient lights, appliances, and conscientious home occupants, the energy generated by the solar electric systems exceeded the electric energy used in most homes. Most homes, in fact, had a net credit from the electric utility over the course of a year. On the natural gas side, total gas costs averaged \$377 per year (for heating, water heating, cooking, and clothes drying). Total energy costs were even less - \$337 per year, including all utility fees. The highest annual energy bill for any home evaluated was $\$ 458$; the lowest was $\$ 171$. 


\section{Introduction and Background}

The Consortium for Advanced Residential Buildings (CARB) is an industry team funded through the U.S. Department of Energy Building America Program. CARB is led by Steven Winter Associates, Inc. (SWA), a firm of architects, engineers, and building system consultants with offices in Norwalk, CT; New York, NY; and Washington, DC.

Rural Development, Inc. (RDI) has been a pioneer in developing and building affordable, efficient, sustainable homes. RDI is a not-for-profit agency whose mission is "to advance the right of all people in Franklin County and the North Quabbin region to occupy environmentally responsible, energy efficient, affordable housing and to improve economic independence. Further, RDI strives to promote environmental awareness, and to operate in a manner that is respectful of the rural character of our region.”

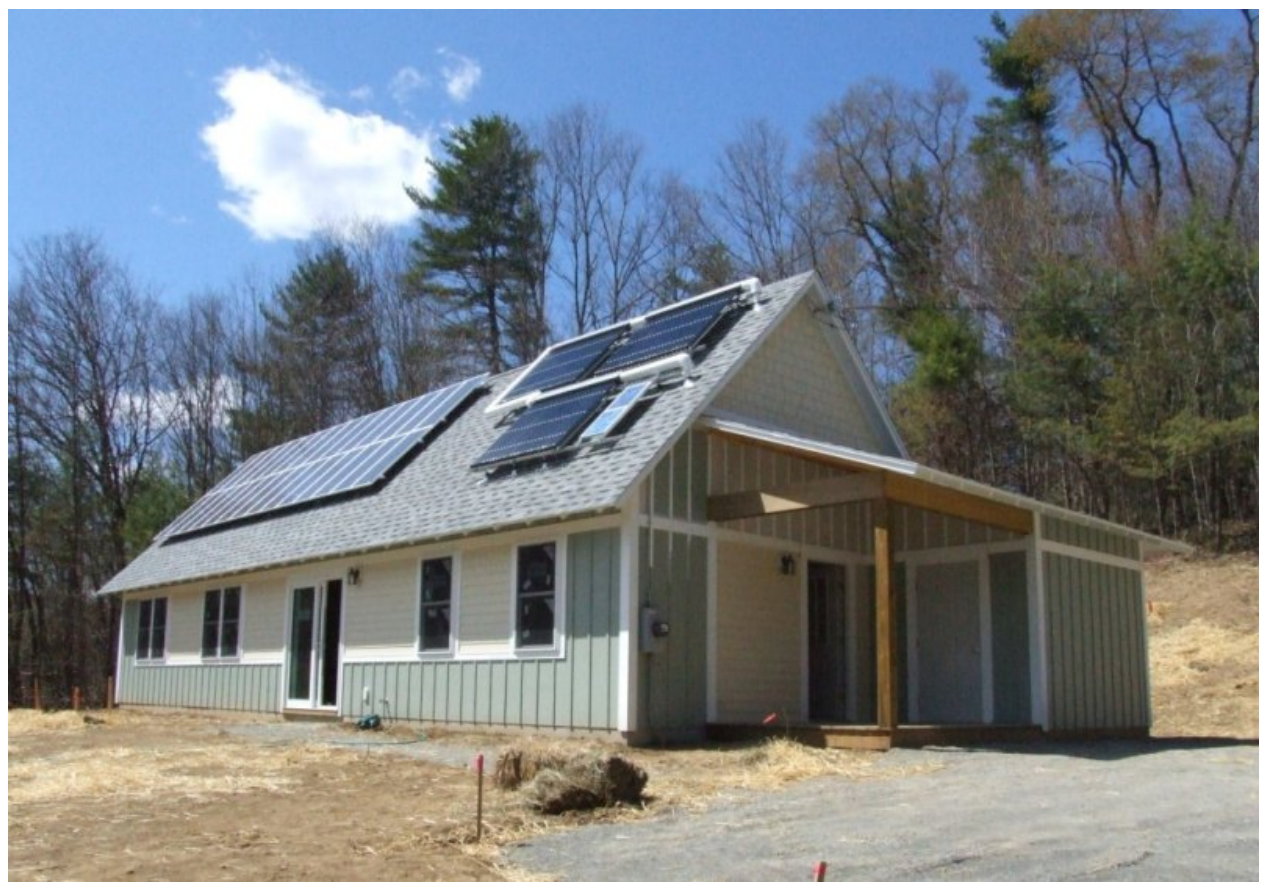

Figure 1. RDI's prototype "near zero energy" home in Colrain, MA. The home was completed in May, 2007.

RDI began participating in utility sponsored ENERGY STAR ${ }^{\mathrm{TM}}$ programs in 2000. Since then, RDI has endeavored to steadily improve the performance, efficiency, and overall sustainability of their homes. They began incorporating solar electric systems into ENERGY STAR homes in 2004 (with support from the Massachusetts Technology Collaborative) and received national recognition in 2005 from the Home Depot Foundation with the "Award of Excellence for Affordable Housing Built Responsibly.” Also in 2005, RDI began working with CARB to begin design of a prototype home approaching "zero energy." This prototype home (Figure 1) was completed in Colrain, MA in May of 2007, and CARB closely monitored the construction process and monitoring the energy systems for three years after completion.

Building on the successes and lessons-learned from this experience, RDI began plans for a community of homes reaching again for near-zero energy levels. RDI worked closely with 
architects at Austin Design (designers of the prototype home) and engineers at CARB to plan the community. Located on Wisdom Way in Greenfield, MA, RDI chose to name the project "Wisdom Way Solar Village."

Wisdom Way Solar Village (WWSV) consists of ten duplexes (twenty dwelling units total) including two-, three-, and four-bedroom homes. Eighteen of the 20 homes are for homeownership; two will be fully accessible and rented by RDI to residents with disabilities. All of the homes are "visitable" by persons in wheelchairs. The first unit was completed in late 2008; the last homes were completed in September 2010. CARB has obtained utility bill information from 13 of the occupied homes.

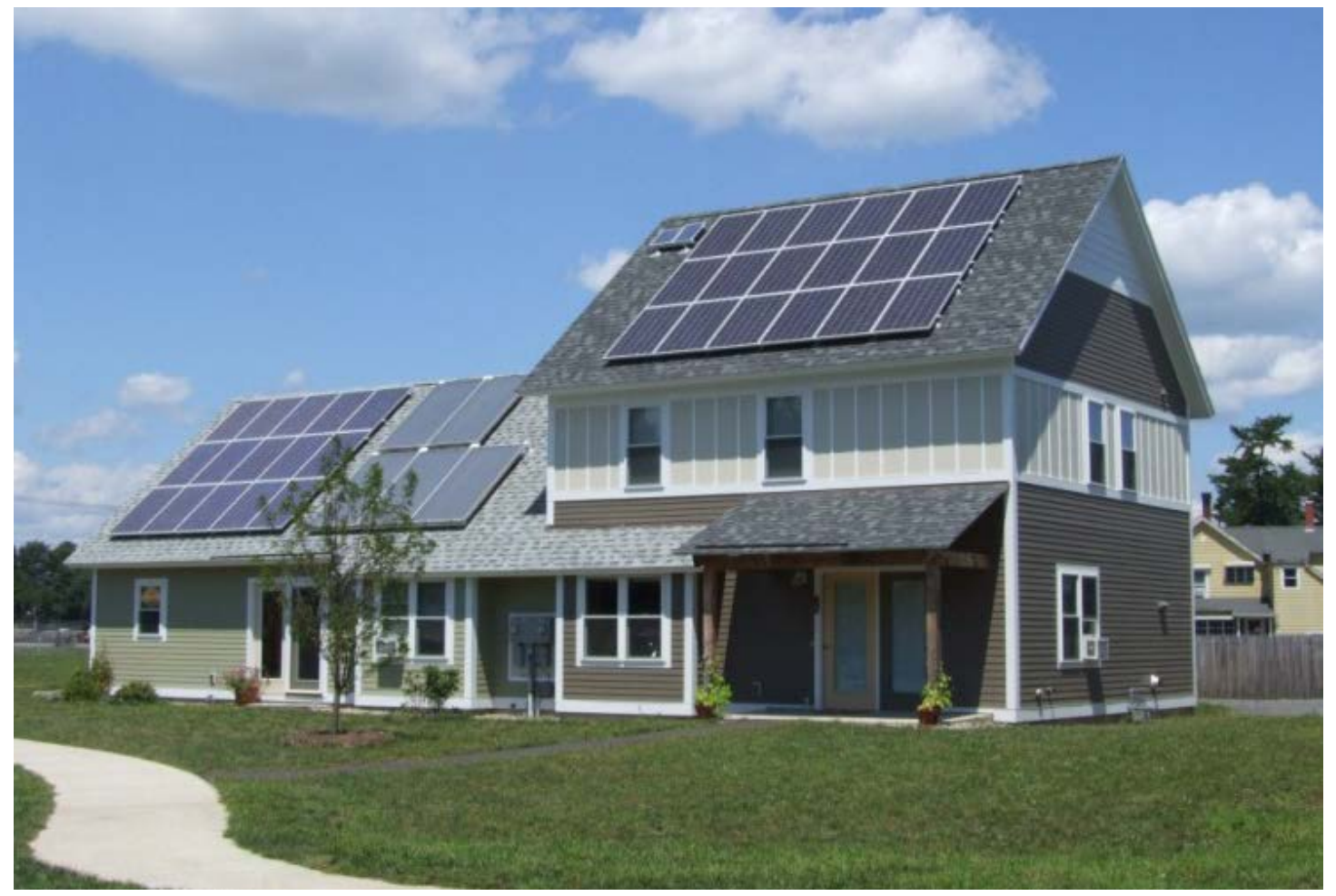

Figure 2. One of the completed WWSV duplexes.

\section{Planning and Design}

\subsection{Project Team}

RDI saw real value in assembling a design team very early on in the project - even before the land was acquired. In addition to several people from RDI (the builder and developer), the design team included architects (again from Austin Design), the civil engineer, the landscape architect, the mechanical engineer, RDI's lawyer, solar contractors, plumbers, the electrician, site and foundation contractors, a utility representative, the home energy rater, and other specialists as needed. Not every member of the team attended every meeting, but having this group of committed professionals willing and able to address problems and meet as needed was critical to the project's success. The team continued working together to address concerns and resolve issues as the build-out of the project progressed. 
In addition to the professional design team, RDI also organized periodic meetings with interested members of the community and potential home buyers to evaluate their concerns and suggestions for the project.

Many members of the design team met to discuss the potential for the project before the land was purchased. It was determined that the site could support 20-25 dwelling units and still leave substantial room for open space. Designers worked with the town of Greenfield to evaluate various development options; the final plans called for a condominium community consisting of twenty dwelling units in ten duplexes.

\subsection{Site Planning}

Site planning is one of the most important - but often overlooked - elements in designing communities of high-performance homes. This infill site was a very level field with very few trees or other obstructions. Until recently, the site had been used as overflow parking for the nearby county fairgrounds. The design team met very early in the process to consider:

- Creating a "neighborhood" rather than a typical, suburban development

- Providing open space for recreation, gardening, etc.

- Incorporating utilities and roads efficiently

- Southern orientation for all homes to allow for passive and active solar

- Functional landscaping that would not cause detrimental shading

- Making the community accessible to people with disabilities

The design team explored various clustered development options, but the site plan finally approved by town officials is shown in Figure 3. The ten duplexes (twenty units) were sited to ensure solar access for all homes. Open space is preserved in the northwest corner of the site, and a narrow strip on the western edge of the block (which is shaded by tall trees to the west) is also left open. CARB worked with RDI and Joan Rockwell \& Associates, the landscape architect, to specify maximum mature heights for plantings so solar access to homes would not be compromised now or in the future. 


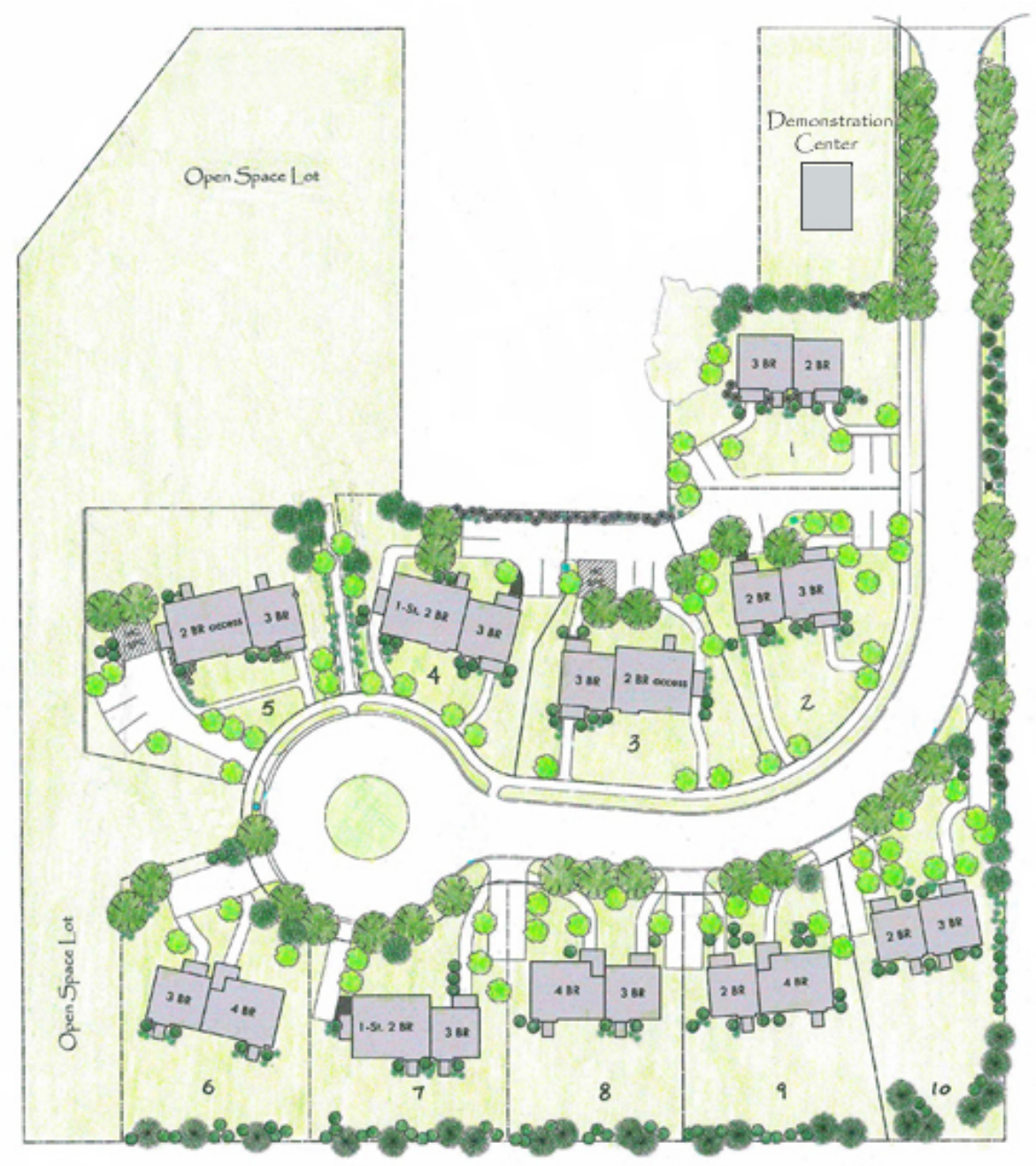

Figure 3. Site and landscape plan from Joan S. Rockwell \& Associates. North is directly towards the top of the page.

\subsection{Home Plans}

The community consists of twenty homes in ten duplexes as outlined below:

- Four 2-bedroom, one-story homes (1,137 gross $\mathrm{ft}^{2}$; two of these are fully accessible)

- Four 2-bedroom, two-story homes (1,140 gross $\left.\mathrm{ft}^{2}\right)$

- Nine 3-bedroom, two-story homes $\left(1,390\right.$ gross $\left.\mathrm{ft}^{2}\right)$

- Three 4-bedroom, two-story homes (1,773 gross $\left.\mathrm{ft}^{2}\right)$

Typically, the homes feature an open downstairs plan containing living, dining, and kitchen areas as well as a powder room. Upper floors generally contain bedrooms and a full bath. In singlestory homes, the living, dining, and kitchen areas are towards the south, while the bedrooms and bathroom are towards the north. Plans for one duplex, showing a 2-bedroom and 3-bedroom unit, are shown in the appendix. 


\section{Building Specifications}

In addition to outlining specifications and construction details, this section of the report also describes decision-making processes, challenges that occurred during construction, and recommendations for improving on these construction techniques.

\subsection{Basement}

All homes have full, unconditioned basements. The first-floor joist bays were insulated with $11.5^{\prime}$ of blown cellulose for approximately R-39 $\mathrm{ft}^{2} \mathrm{hr}{ }^{\circ} \mathrm{F} / \mathrm{Btu}$.

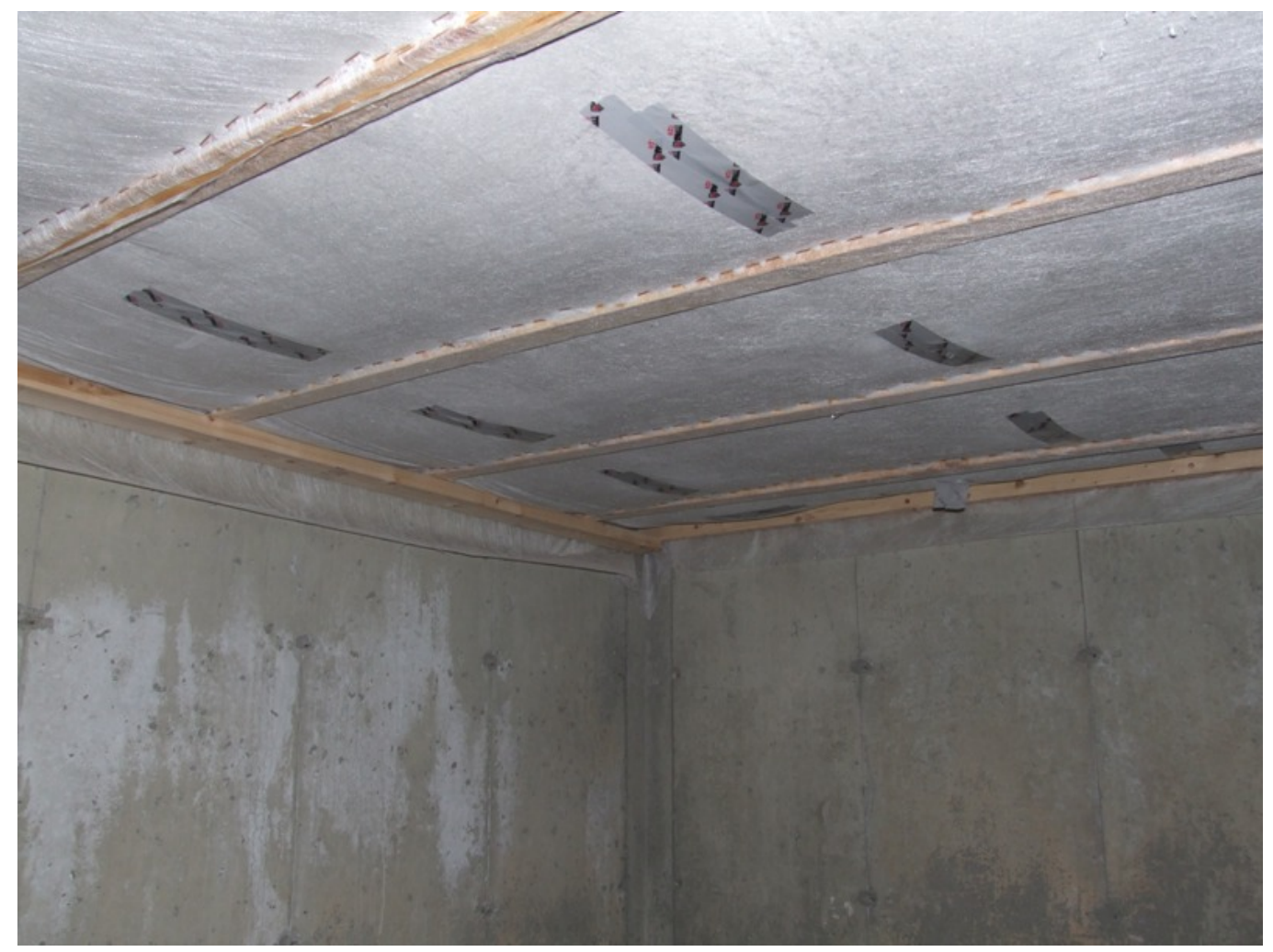

Figure 4. Ceiling of a basement insulated with blown cellulose.

Whenever possible, CARB recommends insulating foundation walls rather than the floors above basements. RDI determined that insulating the floors was much less costly and more practical. Energy modeling showed that R-18 $\mathrm{ft}^{2} \mathrm{hr}{ }^{\circ} \mathrm{F} /$ Btu rigid foam insulation (3” of polyisocyanurate) adhered to the walls would be necessary to achieve the same overall energy performance as the R-39 floors. The blown cellulose was considerably less expensive and simpler to install. In many areas, foil-faced polyisocyanurate foam is approved for this application and can be left exposed in basements. At this site, however, RDI believed that the local code officials would require that the foam be covered with drywall, further increasing the cost.

\subsection{Above-Grade Walls}

One of the key features in the prototype home in Colrain, MA was the double-wall construction. This was repeated at Wisdom Way Solar Village in Greenfield. Each exterior wall begins with a load-bearing, $2 \times 4$ framed wall (framing at 16" on center). Carpenters then enclose the entire envelope (wall sheathing, roofing, windows, doors, etc.). Once the home is enclosed, carpenters 
begin interior framing and construct an additional 2x4 wall five inches inside of the existing, exterior wall. Fiber-reinforced polyethylene or insulation netting is stapled to the inner studs, and the entire 12" wall cavity is filled with dry-blown cellulose insulation at densities of at least 3.4-4 lbm/ft ${ }^{3}$. The cellulose manufacturer recommends higher-than-average insulation densities to prevent settling in such large wall cavities.

In the first two duplexes built, reinforced polyethylene was installed as a vapor barrier on the inside of the wall. A vapor barrier such as this was required by the Massachusetts code, but the design team felt strongly that the wall would be more durable - more forgiving of moisture intrusion - if the wall could dry somewhat to the inside of the home. RDI approached the Greenfield building department to assess options for dropping the polyethylene, and the building department did eventually allow this after receiving stamped letters from architects and engineers.

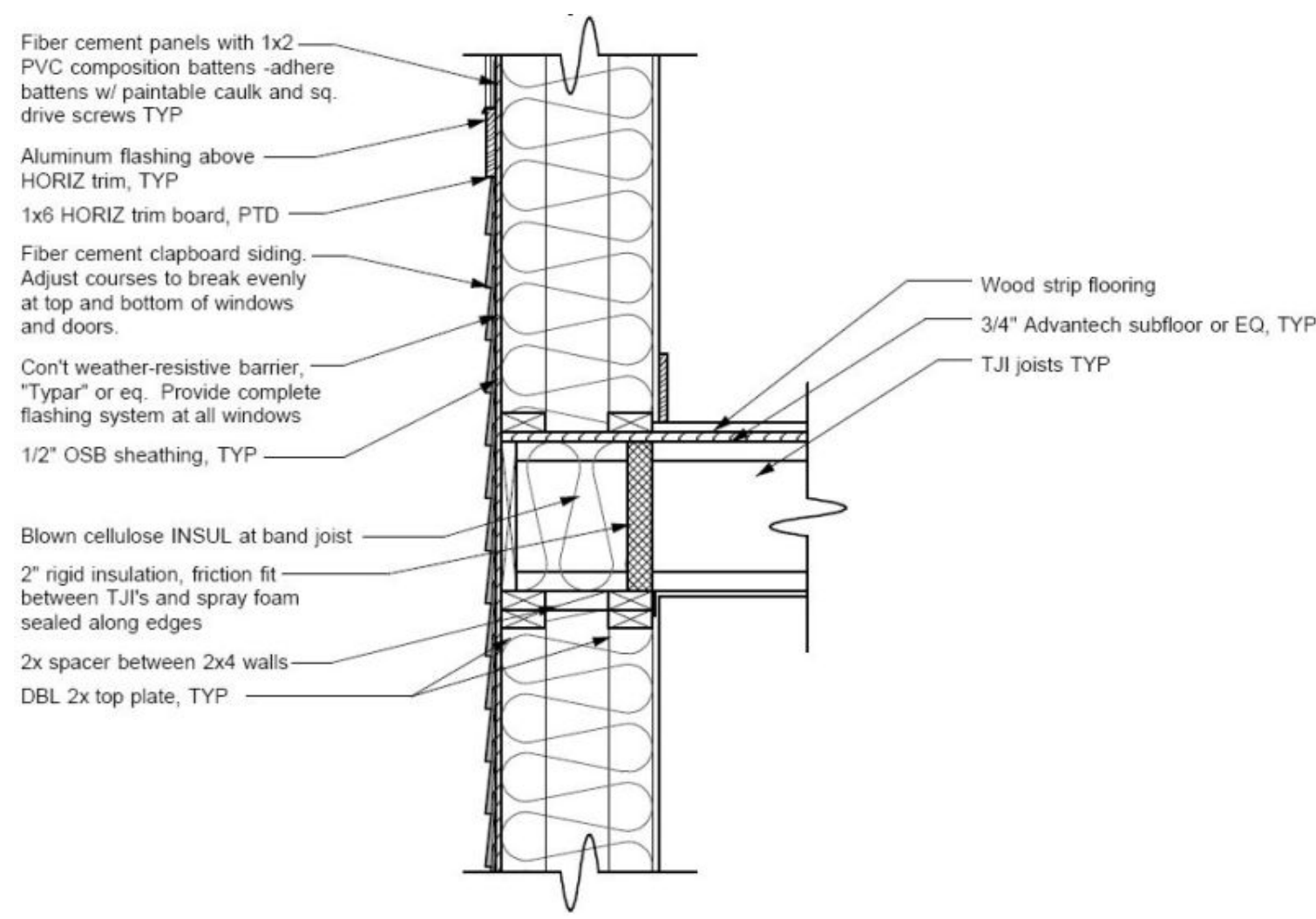

Figure 5. Typical wall section from Austin Design, Inc. Insulation netting was used in stead of rigid insulation between floor joists. 

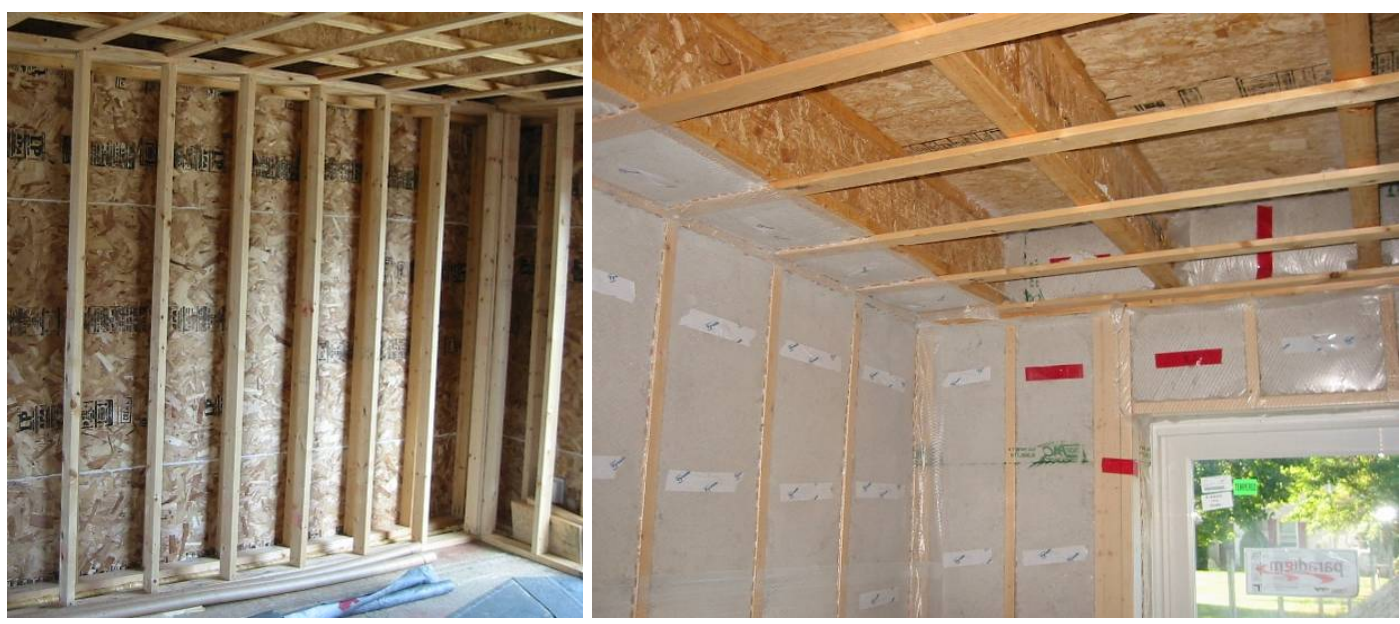

Figure 6. Double walls before and after cellulose insulation.

Planning for wall penetrations is critical with double wall construction. Several venting challenges required on-site meetings to coordinate venting and insulation. Around dryer exhaust, exhaust fans, combustion venting, and other plumbing penetrations, RDI carpenters made special insulation accommodations (see Figure 7). A separate compartment of insulation netting was installed around vents, and these compartments were blown separately. In this way, if these penetrations needed to be accessed for any reason, only the small amount of insulation surrounding them need be removed; otherwise, insulation in the entire wall could be compromised.

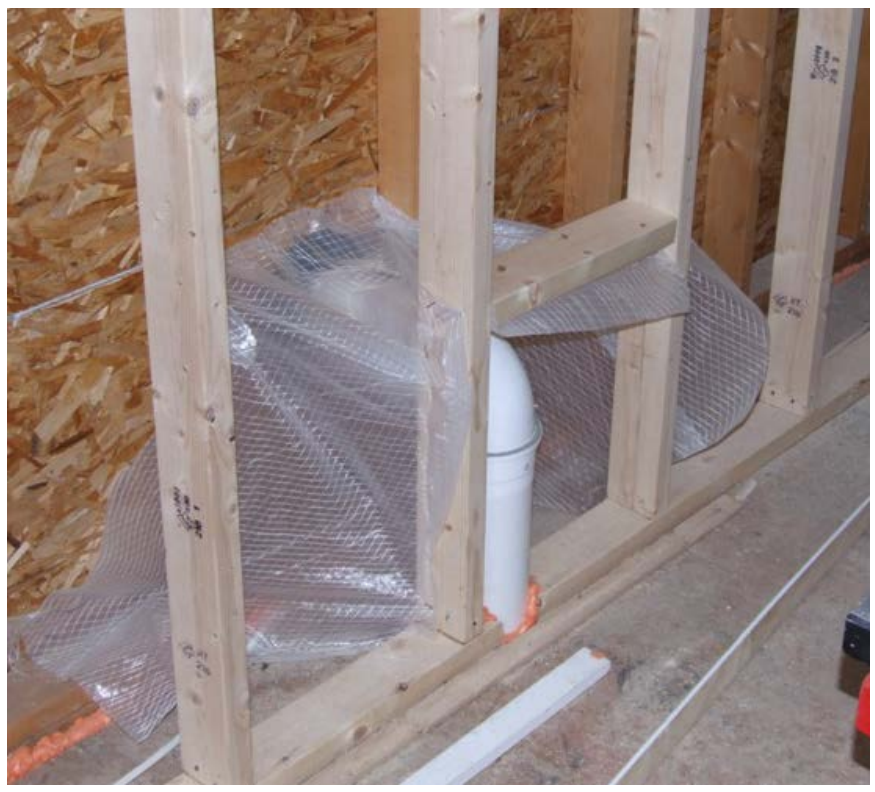

Figure 7. Insulation netting surrounding water heater combustion air and exhaust piping. These small areas were insulated separately to allow access if needed in the future.

The double-wall construction seemed to work very well for RDI for two key reasons:

- The homes are designed with double-wall construction in mind. The perimeters of the homes are basically rectangular with very few interruptions (each home has one box bay). 
Employing the double-wall technique on more complicated plans with more dormers, gables, angles and bays, etc. would be more time- and material-intensive.

- RDI had a core group of carpenters (RDI employees) that built the homes. RDI did not have to rely on (or train) outside framing contractors for this specialized job.

These factors kept the added costs for double walls lower. CARB surveyed RDI's carpenters and insulators to assess the added time and material needed for these double wall systems. These estimates are shown in Table 1.

Table 1. Approximate incremental costs for double-wall construction in a 3-bedroom home at WWSV. Costs are compared to conventional $2 \times 6$ construction with blown cellulose.

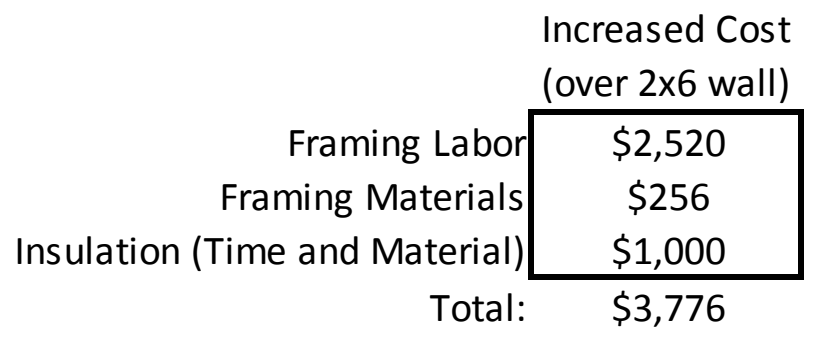

\subsection{Attic}

Roofs of the home are constructed with manufactured, raised-heel trusses. Vented attics incorporate full soffit and ridge vents and full insulation baffles at every truss bay. Homes are insulated with 14" of loose-blown cellulose for an R-value of approximately $50 \mathrm{ft}^{2} \mathrm{hr}{ }^{\circ} \mathrm{F} / \mathrm{Btu}$. Incremental cost for this insulation (over the typical R-38) was approximately $\$ 300$ per home.

\subsection{Windows}

RDI had typically obtained low-e, vinyl-framed windows from Paradigm Windows, a manufacturer based in Portland, ME. Paradigm makes double-pane, low-e window with foamfilled frames that achieve U-values of $0.26 \mathrm{Btu} / \mathrm{ft}^{2} \mathrm{hr}{ }^{\circ} \mathrm{F}$ and solar heat gain coefficients (SHGCs) of 0.28 .

At the prototype home in Colrain, MA, Paradigm provided windows with a Heat Mirror ${ }^{\mathrm{TM}}$ membrane. The Heat Mirror product is a low-emissivity, polymer film that is suspended between the two panes of glass, effectively acting as a third pane. These windows had U-values of $0.20 \mathrm{Btu} / \mathrm{ft}^{2} \mathrm{hr}{ }^{\circ} \mathrm{F}$ and SHGC of 0.25 . While Paradigm provided these windows for the prototype at no incremental cost (above the standard double-pane windows), the normal cost of these windows to RDI would have been twice that of the double-pane, low-e windows.

For the Wisdom Way development in Greenfield, RDI again planned to use the Heat Mirror products, despite the cost. However, Paradigm's supplier of the Heat Mirror IG units could no longer provide product. Paradigm, therefore, began offering a triple-pane window product with similar thermal performance: U-value of $0.18 \mathrm{Btu} / \mathrm{ft}^{2} \mathrm{hr}{ }^{\circ} \mathrm{F}$, SHGC of 0.23 . While these windows would provide excellent thermal performance, the visible transmittance (VT) of the windows was rather low -0.37 .

Partly because of the low visible transmittance, RDI set out to find windows with higher visible light performance and - at least for the southern elevations - windows with higher solar heat gain coefficients. While these homes do not have a tremendous amount of southern glazing (88 
$\mathrm{ft}^{2}$ in the 3-BR unit modeled), higher solar gain in southern windows can offset a small amount of gas use.

CARB worked with RDI to find windows with higher solar gain (ideally 0.50 or above) and visible transmittance, but with U-values still near $0.20 \mathrm{Btu} / \mathrm{ft}^{2} \mathrm{hr}^{\circ} \mathrm{F}$. The search was not fruitful; CARB and RDI contacted approximately 20 different window manufacturers (many in Canada), but none was able to provide vinyl-framed windows with the desired properties (only windows with very low SHGC were found). Several manufacturers of custom, fiberglass windows could meet the desired performance, but pricing of these windows was well beyond what the project could afford. CARB also contacted window researchers at Lawrence Berkeley National Laboratory who provided contacts of several glazing manufacturers. These contacts, however, failed to lead to providers of affordable triple-pane windows with the desired properties.

RDI also worked with Paradigm to see if they could manufacture a window with these properties, but Paradigm was not equipped to manufacture such products. Paradigm did, however, offer to provide double-pane windows with the low-e coating on surface 3 (basically the reverse of their typical low-e product) which raised the solar heat gain coefficient to 0.37. The final specification for windows at the Wisdom Way Solar Village is shown in Table 2.

Table 2. Window properties at Wisdom Way Solar Village.

\begin{tabular}{lclcccc}
\multicolumn{1}{c}{ Orientation } & Manufacturer & \multicolumn{1}{c}{ Description } & $\begin{array}{c}\text { U-value } \\
{\left[\mathrm{Btu} / \mathrm{ft}^{2} \mathrm{hr}{ }^{\circ} \mathrm{F}\right]}\end{array}$ & SHGC & VT \\
\hline South & Paradigm & $\begin{array}{l}\text { Double-pane, low-e } \\
\text { on surface 3 }\end{array}$ & 0.26 & 0.37 & 0.53 \\
\hline North, East, West & Paradigm & $\begin{array}{l}\text { Triple-pane, low-e } \\
\text { on surfaces 2 and 5 }\end{array}$ & 0.18 & 0.23 & 0.37
\end{tabular}

Cost of the triple-pane windows was approximately $\$ 35 / \mathrm{ft}^{2}$, 55\% more than the $\$ 23 / \mathrm{ft}^{2}$ for double pane windows. This increased the window cost for a 3-bedroom WWSV home by $\$ 1,436$.

\subsection{Air Sealing}

Since RDI began building ENERGY STAR homes, they have paid more and more attention to creating air-tight envelopes. Sealing joints in sheathing, around windows and doors, all penetrations in plates and walls, etc. is standard practice. Blower door testing on the WWSV homes showed leakage in the range of 200-350 CFM when homes were depressurized to $50 \mathrm{~Pa}$.

\subsection{Heating Systems}

Because of the superb envelope, the design heat loads of these units are very small: 10,000 $13,500 \mathrm{Btu} / \mathrm{hr}$. With the very small loads, RDI chose a very small, simple heating system: a sealed-combustion, natural gas-fired room heater located in the central area on the first floor of every unit. The unit is a Monitor Products model GF1800; capacity is 10,200 Btu/h at low fire, $16,000 \mathrm{Btu} / \mathrm{h}$ on high fire, and the AFUE is $83 \%$. The location of the heater is shown on floor plans in the appendix.

In previous projects, RDI's standard heating system has been an ENERGY STAR boiler (either gas or oil) fueling hydronic baseboard convectors. The unit heater system results in savings of approximately $\$ 4,000$ and helps offset the significantly higher envelope costs. 
CARB has discussed comfort in the homes at length with RDI. To alleviate concerns about temperature differentials - and to improve ventilation performance - CARB worked with RDI to design a very simple air distribution system. This is described more in the "Ventilation Systems" section below. To assure comfort in bathrooms, each full bathroom upstairs contains a small, 500-Watt electric resistance heater. The electric heaters are wired to a crank timer so they cannot be left $\mathrm{ON}$ for long periods of time.

In conjunction with NREL, CARB performed short-term thermal comfort testing of one of the first completed Wisdom Way homes in February 2009. As expected, testing found that unoccupied, upstairs bedrooms with doors closed were substantially cooler than the downstairs living room. However, when doors were opened or when a small load was introduced (using a 60-watt lamp), bedroom temperatures were much closer to downstairs temperatures.

CARB followed this short-term testing with tests of four occupied homes during the winter of 2009-2010. This monitoring found that upstairs bedrooms were usually slightly cooler than downstairs spaces (where the heater was located). None of the occupants, however, had major complaints about comfort. Some occupants surveyed were quite pleased, saying that comfort in the home exceeded expectations. Much more information about these heating systems, test results, occupant interviews, and other implications of these systems can be found in CARB's report "Point-Source Heating Systems in Cold-Climate Homes: Wisdom Way Solar Village” (CARB2010).

\subsection{Ventilation Systems}

As with most of RDI's homes, the WWSV dwellings use an exhaust-only ventilation strategy. In the primary bathroom of each home (the bathroom with a shower), a Panasonic Whisper Green exhaust fan (model no. FV-08VKSL1) is installed and programmed to run continuously to meet the whole-building ventilation requirements of ASHRAE Standard 62.2-2007 (30-60 CFM, depending on the home size). The fan is also equipped to boost to high speed (80 CFM) for an adjustable amount of time when the bathroom is in use.

Exhaust-only ventilation is a common, affordable ventilation system for small homes in northern climates where air conditioning and duct systems are not always installed. For RDI - a developer of affordable housing for many first-time homeowners - an additional appeal of exhaust-only systems is the very low maintenance required. From an energy standpoint, new exhaust fans with BPMs typically use 5-11 Watts. With such low power consumption, the overall energy and operating costs of these exhaust-only systems are less than those of some HRVs or ERVs.

CARB and NREL conducted tracer gas testing at the RDI prototype home in Colrain, MA; this home also had exhaust-only ventilation. One of the findings here was that when all doors in the space are closed, some parts of the home experience fewer air changes than others. While it's unclear if this presents a real problem with indoor air quality, it may not be ideal.

In homes at the Wisdom Way Solar Village, CARB has worked with RDI to incorporate a simple, air distribution system to minimize discrepancies in air changes. As an added benefit, the system also helps to equalize air temperatures between spaces in the home. Each home contains an additional Panasonic WhisperGreen fan which "exhausts" air from the ceiling of the 
first floor and distributes a small amount of air (20-25 CFM) to each bedroom. Mechanical plans showing equipment and duct layouts are included in an appendix.
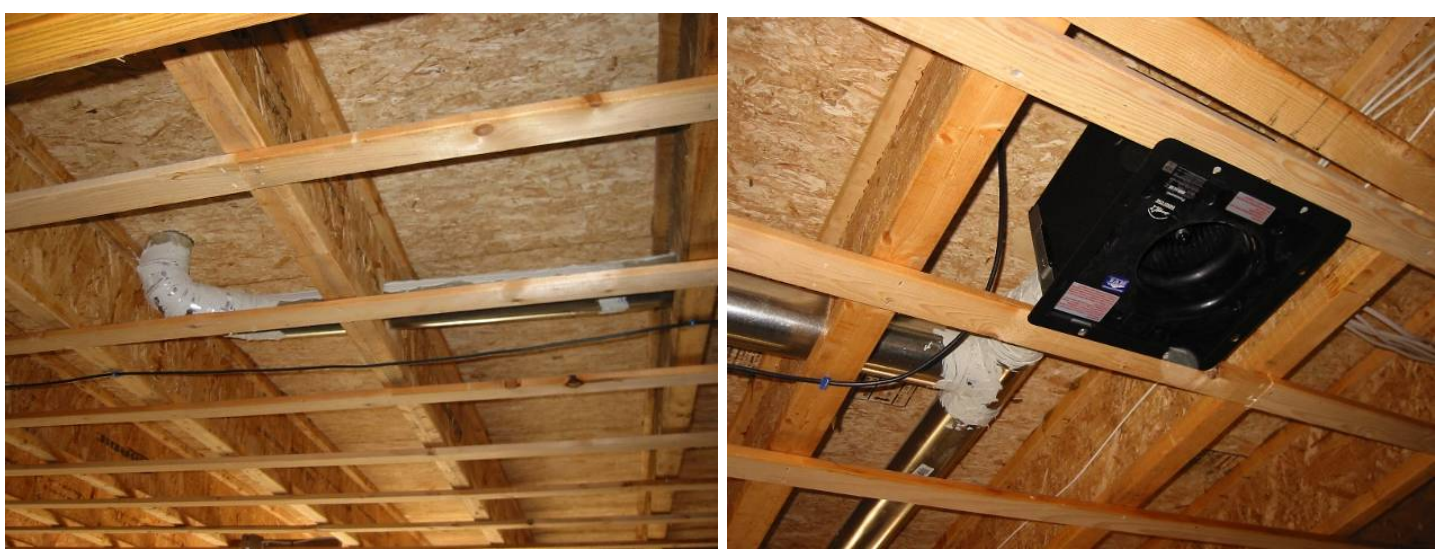

Figure 8. The exhaust fan and simple duct distribution system installed between the first and second floors.

In conjunction with NREL, CARB performed multi-point tracer-gas testing to evaluate air changes throughout the homes. Results showed that the simple air distribution system truly does improve mixing of fresh air. During one tracer gas test when all interior doors were closed and the distribution system was turned off, the reciprocal average age of air ranged from $0.15 \mathrm{hr}^{-1}$ in one bedroom to $0.30 \mathrm{hr}^{-1}$ in the living room. When the distribution system was turned on, reciprocal average age of air ranged only from $0.27 \mathrm{hr}^{-1}$ in one bedroom to $0.32 \mathrm{hr}^{-1}$ in the living room (in a home with perfect mixing of outdoor air, reciprocal age of air would be equal in all rooms).

For more information on these tests, see CARB's report "Point-Source Heating Systems in ColdClimate Homes: Wisdom Way Solar Village” (CARB 2010). For more information on the "Reciprocal Age of Air" tests and analysis methods, see (Barley).

\subsection{Lights and Appliances}

RDI participated in an ENERGY STAR program sponsored by the local utility (Western Massachusetts Electric Company, WMECO). As part of this program, RDI received screw-in compact fluorescent lamps in all fixtures throughout the homes. All appliances provided by RDI (refrigerators and dishwashers) are also ENERGY STAR rated.

\subsection{Water Heating}

Most of the energy needs for domestic water heating in the homes is provided by solar thermal systems. Flat-plate solar collectors are mounted on the southern roof of each home, and a propylene glycol antifreeze solution is circulated between the collectors and a heat exchanger located in a 110-gallon storage tank in the basement. A direct-current pump circulates the glycol; the pump is powered by a dedicated 20-30 Watt PV module. Auxiliary water heating in each home is provided by a sealed-combustion, natural gas-fired, tankless water heater installed in the basement near the solar tank. Three- and four-bedroom homes have three, $29-\mathrm{ft}^{2}$ solar thermal collectors; two-bedroom units have two collectors. 
As the photos show (Figure 2, Figure 12), southern roof space was limited in these homes. RDI's original plans called for solar thermal systems to provide a portion of the space heating load as well as water heating. To provide any substantial portion of the load, however, RDI would need one or two additional solar thermal collectors; there was simply no roof space to support these collectors.

\subsection{Solar Electric Systems}

Each home has a solar electric system installed on the roof. Two-bedroom homes have 2.84$\mathrm{kW}_{\mathrm{STC}} \mathrm{PV}$ systems; three- and four-bedroom homes have $3.42-\mathrm{kW}_{\mathrm{STC}}$ systems. All systems are installed flush on the roof (10/12 pitch, $40^{\circ}$ tilt) and facing within $10^{\circ}$ of true south. Each system has one inverter which is located in the basement of each home.

\section{Modeling Methods}

\subsection{Building America Benchmark Analyses}

CARB conducted building energy analyses to compare the energy use of these homes to the Building America Research Benchmark (Definition 12/20/2007) and to a code compliant home. This version of the Building America Research Benchmark Definition was consistent with mid1990s standard building practice for a particular climate zone. Greenfield, MA falls in the cold climate zone (DOE's climate zone 5). Greenfield has approximately 7,200 degree-days per year $\left(65^{\circ} \mathrm{F}\right.$ base) and 2,200 cooling degree-hours ( $74^{\circ} \mathrm{F}$ base). The $99 \%$ heating design temperature is $2^{\circ} \mathrm{F}$.

CARB used EnergyGauge USA v2.7.03 (EGUSA), an hourly energy simulation tool, to model the energy performance of a 3-bedroom home. Performance of the solar thermal system was modeled with F-Chart software, and PV generation was calculated using NREL's PVWatts tool. This 3-bedroom unit is a mid-sized home for the development, and it is also the most common accounting for 9 of the 20 homes. According to these analyses, the home will require $57 \%$ less source energy to operate than a home built to the benchmark definition. When the PV generation is included, source energy savings is $77 \%$ when compared to the benchmark home. Table 3 shows the modeled site energy by end use, and Table 4 shows the source energy used in a 3bedroom home at RDI's Wisdom Way development.

Table 3. Modeled site energy of 3-bedroom home compared to the baseline home (using Building America Benchmark procedures, 12/20/2007).

\begin{tabular}{|c|c|c|c|c|}
\hline \multirow[b]{3}{*}{ End-Use } & \multicolumn{4}{|c|}{ Annual Site Energy } \\
\hline & \multicolumn{2}{|c|}{ Benchmark } & \multicolumn{2}{|c|}{ Prototype } \\
\hline & kWh & Therms & kWh & Therms \\
\hline Space Heating & 739 & 1024 & 212 & 258 \\
\hline Space Cooling & 851 & 0 & 547 & 0 \\
\hline DHW & 0 & 242 & 0 & 53 \\
\hline Fixed Lighting & 1490 & & 415 & \\
\hline Appliances & 1056 & 98 & 937 & 98 \\
\hline Plug Load & 2578 & 11 & 2578 & 11 \\
\hline Plug-in Lighting & 309 & & 86 & \\
\hline OA Ventilation & 190 & & 53 & \\
\hline Total Usage & 7213 & 1375 & 4828 & 420 \\
\hline Site Generation & & & 4060 & \\
\hline Net Energy Use & 7213 & 1375 & 768 & 420 \\
\hline
\end{tabular}


Table 4. Modeled source energy of 3-bedroom home compared to the baseline home (using Building America Benchmark procedures, 12/20/2007).

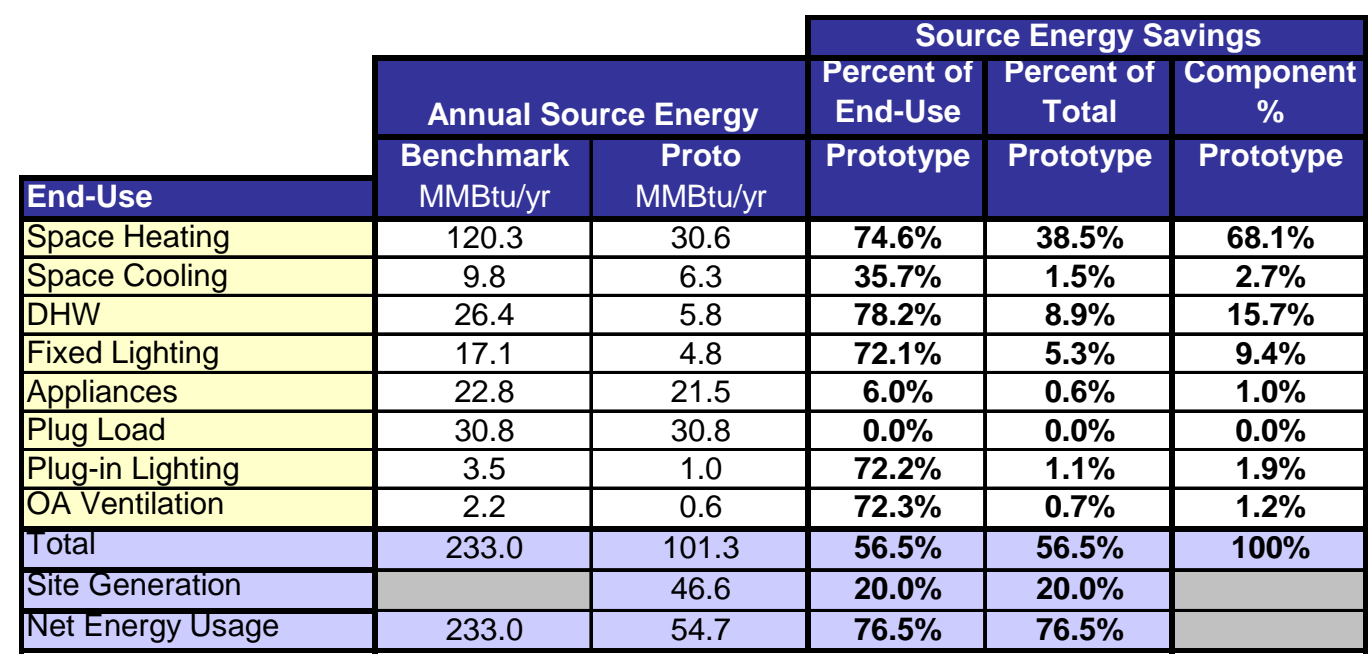

\subsection{REM/Rate Modeling}

SWA performed REM/Rate analyses in addition to Building America benchmark modeling. REM/Rate is the modeling tool used by most home energy raters in the region, and SWA has found that it provides accurate predictions of heating energy use. Models assumed infiltration of 350 CFM50 for all homes; blower door testing ultimately revealed that infiltration was below this value for most (if not all) homes.

While REM/Rate typically provides very accurate heating energy predictions, other values are much harder to predict as they depend more heavily on habits of the home occupants. A summary of the modeling is presented in Table 5 and Table 6. Table 7 shows the associated costs predicted at current utility rates.

Table 5. Results of REM/Rate modeling on natural gas use in each home type.

\begin{tabular}{lcccc} 
& \multicolumn{4}{c}{ Modeled Annual Gas Use [Therms] } \\
\cline { 2 - 5 } & $\begin{array}{l}\text { 2-BR } \\
\text { (1-story) }\end{array}$ & $\begin{array}{c}\text { 2-BR } \\
\text { (2-story) }\end{array}$ & 3-BR & 4-BR \\
\cline { 2 - 5 } Space Heating & 177 & 182 & 185 & 242 \\
Water Heating & 14 & 14 & 24 & 20 \\
Other & 74 & 74 & 89 & 104 \\
Total: & 265 & 270 & 298 & 366 \\
\hline
\end{tabular}


Table 6. Results of REM/Rate modeling of electricity use and generation in each home type.

\begin{tabular}{lllll} 
& \multicolumn{4}{c}{ Modeled Annual Electricity [kWh] } \\
\cline { 2 - 5 } & 2-BR & 2-BR & & \\
& (1-story) & (2-story) & 3-BR & 4-BR \\
\cline { 2 - 5 } Consumption & 1,765 & 1,769 & 1,935 & 2,300 \\
Generation & 3,394 & 3,394 & 4,087 & 4,087 \\
Net & $(1,629)$ & $(1,625)$ & $(2,152)$ & $(1,787)$ \\
\hline
\end{tabular}

Table 7. Modeled energy costs (REM/Rate). Utility fees include $\$ 9.65$ per month for gas and $\$ 8.53$ per month for electric utilities. Energy rates used here are \$1.50 per therm and \$0.14 per $\mathrm{kWh}$.

\begin{tabular}{|c|c|c|c|c|}
\hline & \multicolumn{4}{|c|}{ Modeled Annual Energy Costs } \\
\hline & $\begin{array}{c}\text { 2-BR } \\
\text { (1-story) }\end{array}$ & $\begin{array}{c}\text { 2-BR } \\
\text { (2-story) }\end{array}$ & 3-BR & 4-BR \\
\hline Total Utility Fees & $\$ 218$ & $\$ 218$ & $\$ 218$ & $\$ 218$ \\
\hline Gas Cost & \$ 398 & $\$ 405$ & $\$ 447$ & $\$ 549$ \\
\hline Electricity Cost & $\$(228)$ & \$ (228) & $\$(301)$ & $\$(250)$ \\
\hline Net Cost & $\$ 388$ & $\$ 396$ & $\$ 364$ & $\$ 517$ \\
\hline
\end{tabular}

REM/Rate energy consumption predictions are notably less than Building America Benchmark analyses using EnergyGauge USA software. This is discussed further in the "Modeling Comparisons" section below.

\section{Results}

\subsection{Electric Bills}

All buyers of the WWSV homes agreed to allow RDI and SWA to access their utility bill information. CARB was able to access natural gas and electricity consumption data from thirteen homes that have been occupied for at least one year (or very nearly one year in some cases).

From the electric utility, CARB was most often able to obtain net energy consumption (or generation); details about actual consumption and PV generation were not available. Figure 9 shows average, net daily energy use in each of the homes for which CARB obtained data.

For the most recent 12 months (mid-June 2010 through mid-June 2011), CARB obtained net electricity consumption data for 11 occupied homes. Of these 11, nine homes generated more energy than they consumed. Six homes generated enough excess electricity to offset all utility fees; these homes have net credits from the electric utility. Table 8 shows an annual summary for these 11 homes. The average home generated an excess $1.6 \mathrm{kWh} /$ day, and the average annual electric utility cost was $\$ 8$. 


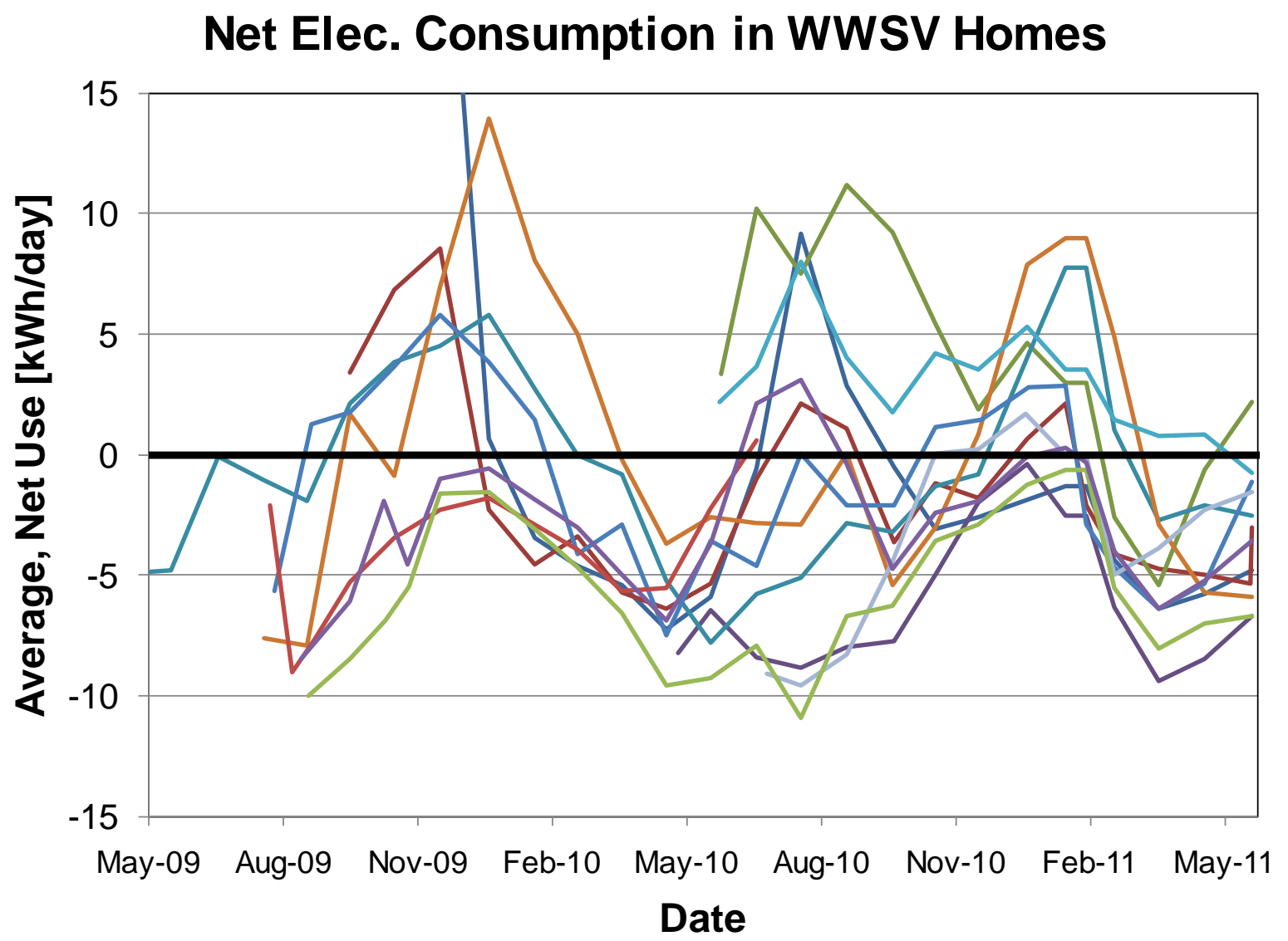

Figure 9. Average, net electricity consumption in WWSV homes from monthly utility bills. Negative values indicate net generation.

Table 8. Summary of electricity bills for $\mathbf{1 1}$ homes.

\begin{tabular}{|c|c|c|c|}
\hline \multirow[b]{2}{*}{ Unit } & \multicolumn{3}{|c|}{12 Mo. Net Electric Use } \\
\hline & $\mathrm{kWh}$ & kWh/day & Cost \\
\hline $2-1 \mathrm{~A}$ & -707 & -1.9 & $-\$ 6$ \\
\hline $2-1 \mathrm{~B}$ & 1112 & 3.0 & $\$ 245$ \\
\hline $2-2 \mathrm{~A}$ & -708 & -1.9 & $-\$ 73$ \\
\hline $2-2 \mathrm{~B}$ & -2256 & -6.1 & $-\$ 216$ \\
\hline $2-2 \mathrm{C}$ & -180 & -0.5 & $\$ 68$ \\
\hline $3 \mathrm{~A}$ & -738 & -2.0 & $-\$ 6$ \\
\hline $3 \mathrm{~B}$ & 1446 & 3.9 & $\$ 289$ \\
\hline $3 \mathrm{C}$ & -427 & -1.2 & $\$ 35$ \\
\hline $3 \mathrm{D}$ & -2062 & -5.6 & $-\$ 189$ \\
\hline $4 \mathrm{~A}$ & -624 & -1.7 & $\$ 12$ \\
\hline $4 \mathrm{~B}$ & -1163 & -3.3 & $-\$ 68$ \\
\hline & Average & -1.6 & $\$ 8$ \\
\hline
\end{tabular}

In Table 8 and elsewhere, the "Unit" designation refers to the number of bedrooms each home has. The second number - when present - indicates the number of stories. For example, Unit 
"2-2 B" is a 2-bedroom, 2-story home; multiple units of the same plan are labeled A, B, C, etc. All 3- and 4-bedroom homes have two stories.

\subsection{Natural Gas Bills}

CARB obtained gas consumption data for 13 occupied homes. Daily average gas consumption from each billing period is shown in Figure 10. Because of a lag in utility bill availability, CARB has a full 12 months of data for only nine occupied homes. Table 9 shows that the average annual gas consumption for these homes was 203 therms for average annual gas costs of \$377, including all utility fees. Total annual gas costs ranged from \$183 to \$485.

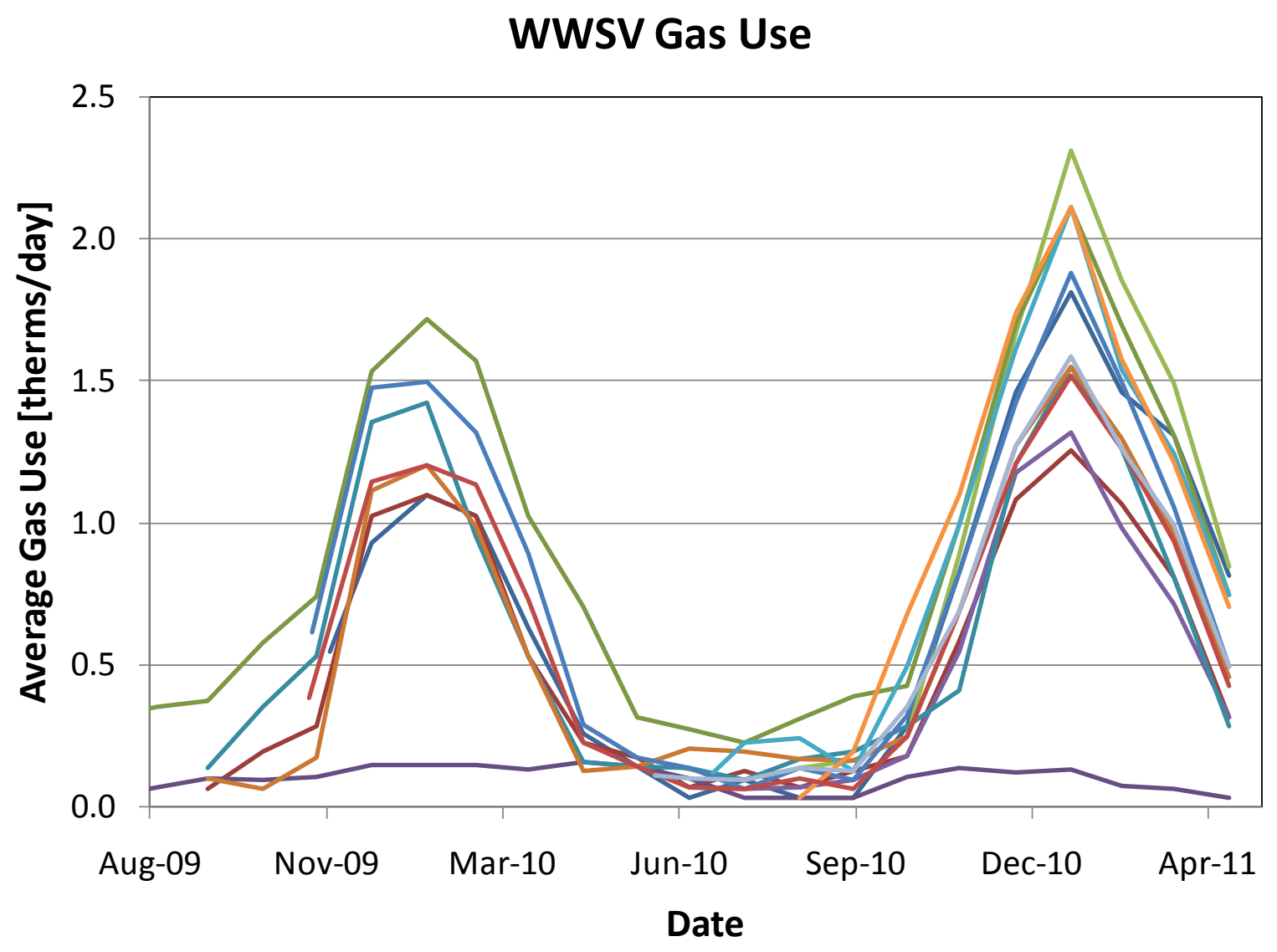

Figure 10. Average natural gas use in 13 occupied WWSV homes.

There is one home (2-2C) for which the data appears suspect. Gas consumption in this home appears extremely low. In the winter, consumption hardly rises (note the purple line in Figure 10). However, CARB has been assured by RDI and neighbors that this home is occupied. RDI has suggested - because of hearsay - that occupants keep the home very cool and use electric resistance heaters to consume electric utility credits. 
Table 9. 12-month gas consumption for nine occupied WWSV homes.

12 Mo. Gas Use

\begin{tabular}{|c|ccc|}
\multicolumn{1}{c}{ Unit } & \multicolumn{1}{c}{ Therms } & Therms/day & Cost \\
\cline { 2 - 4 } 2-1 A & 204 & 0.6 & $\$ 427$ \\
\cline { 2 - 4 } 2-2 A & 252 & 0.7 & $\$ 358$ \\
2-2 B & 174 & 0.5 & $\$ 386$ \\
2-2 C & 31 & 0.1 & $\$ 183$ \\
2-2 D & 224 & 0.6 & $\$ 324$ \\
\hline 3 A & 179 & 0.5 & $\$ 390$ \\
3 C & 319 & 0.9 & $\$ 422$ \\
3 D & 246 & 0.7 & $\$ 485$ \\
\hline 4 A & 199 & 0.5 & $\$ 418$ \\
\hline Average & 203 & 0.6 & $\$ 377$
\end{tabular}

While data from a full year are available from nine homes, data from the previous heating season (October 2010 - April 2011) are available from all 13 occupied homes plus two additional unoccupied homes. As Figure 10 shows, gas consumption from May-September is minimal.

Table 10. Summary of gas consumption during heating season.

\begin{tabular}{|c|cccc|}
\hline & \multicolumn{5}{c}{ 7 Heating Months (Oct'10-Apr'11) } \\
\hline Unit & Therms & Therms/day & \multicolumn{2}{c}{ Cost } \\
\hline 2-1 A & 191 & 0.9 & $\$$ & 351 \\
2-2 B & 202 & 1.0 & $\$$ & 366 \\
\cline { 2 - 5 } 2-2 B & 242 & 1.1 & $\$$ & 314 \\
2-2 C & 160 & 0.8 & $\$$ & 307 \\
2-2 D & 197 & 0.1 & $\$$ & 111 \\
2-2 E & 277 & 1.3 & $\$$ & 265 \\
\cline { 2 - 5 } 3 A & 161 & 0.8 & $\$$ & 309 \\
3 B & 283 & 1.3 & $\$$ & 431 \\
3 C & 273 & 1.3 & $\$$ & 346 \\
3 D & 228 & 1.1 & $\$$ & 403 \\
\cline { 2 - 5 } 4 A & 176 & 0.8 & $\$$ & 330 \\
4 B & 265 & 1.3 & $\$$ & 337 \\
\cline { 2 - 5 } 2-1 Unocc. & 154 & 0.7 & $\$$ & 299 \\
2-1 Unocc. & 144 & 0.7 & $\$$ & 285 \\
\hline Average (Occ'd): & 206 & 1.0 & $\$$ & 325
\end{tabular}

It's worth noting that the gas consumption in the two unoccupied homes - which were kept at approximately $55^{\circ} \mathrm{F}$ with no water heating, cooking, or clothes drying - was only $30 \%$ less than the average consumption for the occupied homes. Internal gains in the occupied homes clearly provide much of the energy needed for space heating. 


\subsection{Total Energy Costs}

Between the two data sets, there are eight occupied homes for which CARB has complete energy bill data for an entire 12 months. As Table 11 shows, average annual energy costs - including all utility fees - ranged from $\$ 171$ to $\$ 458$. The average cost for energy was $\$ 337$, or $\$ 28$ per month.

Table 11. Actual, annual energy costs - including utility fees - for eight occupied WWSV homes.

Annual Cost

\begin{tabular}{|c|c|c|c|}
\hline Unit & Gas & Elec. & Total \\
\hline $2-1 \mathrm{~A}$ & $\$ 427$ & $\$ \quad(6)$ & $\$ 421$ \\
\hline $2-2 \mathrm{~A}$ & $\$ 358$ & $\$(73)$ & $\$ 285$ \\
\hline $2-2 B$ & \$386 & $\$(216)$ & $\$ 171$ \\
\hline $2-2 C$ & \$183 & $\$ 68$ & $\$ 251$ \\
\hline $3 \mathrm{~A}$ & $\$ 390$ & $\$ \quad(6)$ & $\$ 385$ \\
\hline $3 \mathrm{C}$ & $\$ 422$ & $\$ 35$ & $\$ 458$ \\
\hline $3 \mathrm{D}$ & $\$ 485$ & $\$(189)$ & \$297 \\
\hline $4 \mathrm{~A}$ & $\$ 418$ & \$ 12 & $\$ 430$ \\
\hline Averag & \$384 & \$ (47) & \$337 \\
\hline
\end{tabular}

\subsection{Energy Improvement Costs}

CARB worked with RDI, their contractors, and their suppliers to determine incremental costs of the advanced energy features as accurately as possible. An overview of these costs is shown in Table 12. Some estimates are unavoidable, especially with respect to time needed to install or implement these strategies (e.g. the double wall). These costs are specific to energy systems only. For example, RDI spent substantial resources making the homes more accessible and to include sustainable materials; these costs are not reflected below. 
Table 12. Approximate costs for energy improvements to a 3-bedroom RDI home. Incremental costs are compared to Building America Benchmark specifications.

\begin{tabular}{|c|c|c|c|}
\hline \multirow[b]{2}{*}{ Measure } & \multicolumn{2}{|c|}{ Incremental Costs } & \multirow[b]{2}{*}{ Notes } \\
\hline & $\begin{array}{l}\text { Without } \\
\text { subsidies }\end{array}$ & $\begin{array}{c}\text { With } \\
\text { Subsidies }\end{array}$ & \\
\hline Double-wall construction & $\$ 3,776$ & $\$ 3,776$ & From builder calculations and estimates. \\
\hline R-50 attic insulation & $\$ 300$ & $\$ 300$ & Builder cost calculation. \\
\hline R-40 floor insulation & $\$ 540$ & $\$ 540$ & From BEOpt cost estimates. \\
\hline Triple-pane windows & $\$ 1,436$ & $\$ 1,436$ & Actual incremental window costs \\
\hline Heating System & $(\$ 4,500)$ & $(\$ 4,500)$ & $\begin{array}{l}\text { Plumber and builder estimates, including } \\
\text { savings from the standard central boiler with } \\
\text { baseboard. }\end{array}$ \\
\hline Water Heating System & $\$ 0$ & $\$ 0$ & $\begin{array}{l}\text { Cost of tankless comparable to standard indirct } \\
\text { tank. }\end{array}$ \\
\hline Ventilation System & $\$ 600$ & $\$ 450$ & $\begin{array}{l}\text { Cost estimates for distribution system; the } \\
\text { electric utility provided the fan at no cost. }\end{array}$ \\
\hline $100 \%$ CFL & \$114 & $\$ 0$ & $\begin{array}{l}\text { BEOpt estimate of } \$ 3.79 \text { per lamp; utility } \\
\text { provided all CFLs at no cost. }\end{array}$ \\
\hline ENERGY STAR Appliances & $\$ 190$ & $\$ 190$ & $\begin{array}{l}\text { BEOpt incremental costs for ENERGY STAR } \\
\text { refrigerator and dishwasher. }\end{array}$ \\
\hline Solar water heating system & $\$ 9,750$ & $\$ 0$ & $\begin{array}{l}\text { Pricing from solar contractor plus additional } \\
\text { RDI labor. RDI obtained DOE funding for solar } \\
\text { thermal systems. }\end{array}$ \\
\hline 3.4-kW Photovoltaic system & $\$ 24,827$ & $\$ 4,574$ & $\begin{array}{l}\text { State incentives provide funding for PV } \\
\text { systems. }\end{array}$ \\
\hline Total: & $\$ 37,033$ & $\$ 6,766$ & \\
\hline
\end{tabular}

As Table 12 shows, RDI received substantial subsidies for the energy improvements that went into the home. It's also worth considering the relative incremental costs of the envelope improvements $(\$ 6,052)$, mechanical systems (savings of \$3,900), and solar systems $(\$ 34,577)$.

\section{Discussion}

\subsection{Home Size and Energy Use}

An inspection of the tables in the previous section show very little relationship between net energy use and the size of the home. Figure 11 shows average energy use for homes of each size (i.e. homes with 2, 3, and 4 bedrooms). CARB does not have information about the occupancy of all homes; the number of occupants can certainly be a better indicator of energy use than home size. These overall results also include the effects of different PV systems. The 3- and 4bedroom homes have 3.4-kW PV systems; the 2-bedroom homes have 2.8-kW PV systems. 
Energy Use vs. No. Bedrooms

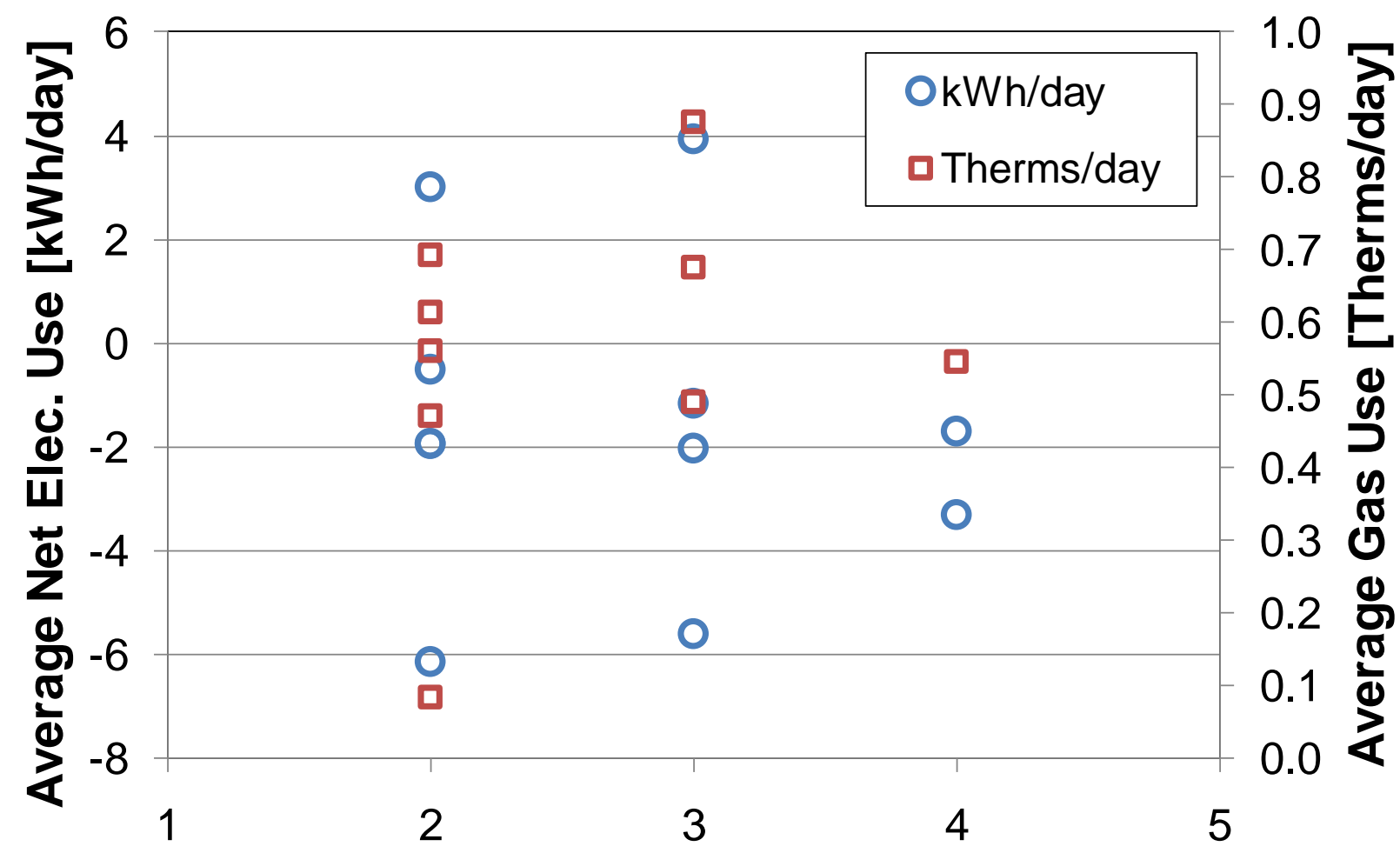

No. Bedrooms

Figure 11. Average energy use for each home vs. number of bedrooms. There seems to be little, if any, correlation between home size and energy use.

\subsection{Modeling Comparisons}

Energy modeling is by necessity approximate, and it cannot account for variations in occupant behavior. However, when data are available from homes such as these, comparisons to modeling can be quite enlightening to evaluate general accuracy, trends, and possible model shortcomings.

\subsubsection{Natural Gas}

Table 13 compares modeled natural gas consumption and average, measured gas used in each type of home. In these homes, modeling predictions were much greater than the actual gas consumed. 
Table 13. Annual natural gas consumption predicted by modeling and actual gas consumed in the homes. *Home 2-2C - which as discussed above had abnormally low gas use - was NOT included in the average below.

\begin{tabular}{l|cccc} 
& \multicolumn{4}{c}{ Natural Gas Use [therms] } \\
\cline { 2 - 5 } & $\begin{array}{c}\text { 2-BR } \\
\text { (1-story) }\end{array}$ & $\begin{array}{c}\text { 2-BR } \\
\text { (2-story) }\end{array}$ & 3-BR & 4-BR \\
\hline REM/Rate & 265 & 270 & 298 & 366 \\
EGUSA/Benchmark & & & 420 & \\
\cline { 2 - 5 } Utility Bills & 204 & $217^{*}$ & 248 & 199 \\
No. Homes & 1 & $3^{*}$ & 3 & 1 \\
\hline
\end{tabular}

For 2- and 3-bedroom homes, REM/Rate predictions are $20-30 \%$ higher than actual readings. In the one 4-bedroom home, REM/Rate's prediction is $84 \%$ higher than measured gas consumption. The predictions made with EnergyGauge USA and the Building America Benchmark procedures were $69 \%$ higher than the average of the three 3-bedroom homes evaluated.

\subsubsection{Electricity}

Looking at the modeled electricity use (Table 14), EnergyGauge USA and the benchmark procedures again predicted much higher energy use than observed. REM/Rate modeling, however, resulted in predictions lower than observed.

Table 14. Modeled and measured electricity consumption in the WWSV homes. The EGUSA values are from the 3-bedroom home.

\begin{tabular}{l|c|} 
& $\begin{array}{c}\text { Annual, Net } \\
\text { Electricity Use } \\
{[\mathrm{kWh}]}\end{array}$ \\
\cline { 2 - 2 } & 768 \\
\hline EGUSA/BA & -1847 \\
\hline REM/Rate & -575 \\
\cline { 2 - 2 } Utility Bills &
\end{tabular}

\subsubsection{Reasons for Modeling Discrepancies}

With respect to predicted electricity use, the disparity between the REM/Rate and EnergyGauge USA / Building America Benchmark models are substantial. Measured electricity consumption falls between the two. There are two key differences in these two modeling procedures which likely explain most of the discrepancies:

- The Benchmark requires modeling of a minimum-efficiency, central air conditioner in homes where the builder does not provide air conditioning. This modeled AC results in an additional $1.5 \mathrm{kWh} /$ day (547 kWh/year). The REM/Rate models include no cooling. While many homeowners did install window air conditioners, it is unlikely consumption was at the rate assumed by Benchmark analyses.

- Benchmark modeling procedures result in a miscellaneous plug load of $7.3 \mathrm{kWh} / \mathrm{day}$ (2,664 kWh/year) in addition to the lights and appliances load of $3.7 \mathrm{kWh} /$ day $(1,352$ kWh/year). The REM/Rate model puts all lights, appliances, and plug loads at 5.3 
kWh/day (1,935 kWh/year) - less than half the benchmark prediction. From the utility data, it seems average loads are between the two.

Reasons for the gas discrepancies are more difficult to identify. Water use in the homes including hot water use - is likely much lower than the default values used in the models. In addition to very efficient appliances, low-flow lavatory faucet aerators ( $0.5 \mathrm{gpm})$ and showerheads (1.5 gpm) are installed throughout the homes. Neither model accounts for these factors, but the main discrepancy in gas use was observed during the heating season.

The winter of 2010-2011 was not a mild winter. The weather site used in REM/Rate modeling (Vernon, VT) has a heating design temperature of $2^{\circ} \mathrm{F}$ and 7,229 heating degree days (base $65^{\circ} \mathrm{F}$ ). Weather data obtained from a nearby weather station in Orange, MA (Orange) shows $7,172 \mathrm{HDD}_{65}$ and 21 days where temperatures dropped below the $2^{\circ} \mathrm{F}$ design temperature. Albany, NY design data, which was used for EnergyGauge USA modeling, shows 6,929 HDD 65 and a design temperature of $2^{\circ} \mathrm{F}$. Warmer temperatures cannot explain the lower-than-expected gas consumption.

CARB suspects one of the largest reasons for lower energy use numbers - for both gas and electricity - is conscientious home occupants. For many buyers of homes in this development, energy efficiency and sustainability were major selling points. It stands to reason that people interested in efficiency would operate their homes more efficiently.

\subsection{Cost Effectiveness}

As Table 12 above shows, total incremental costs for energy improvements in a 3-bedroom WWSV home - above specifications for the Building America Benchmark (Hendron) - were $\$ 37,033$. After considerable subsidies, RDI’s increased costs were $\$ 6,766$. Modeled cost savings (see Table 15) were $\$ 2,335$ per year. When subsidies are included, the energy savings provide an effective rate of return of $35 \%$ on the efficiency investments (over a 30-year evaluation period). If subsidies are not included, the modeled rate of return is a much more modest $4.7 \%$.

Table 15. Summary of modeled and measured energy costs for a 3-bedroom WWSV home. Electricity costs are $\$ 0.14 / \mathrm{kWh}$ and $\$ 8.63 /$ month. Gas costs are $\$ 1.40 /$ therm and $\$ 9.65 / \mathrm{month}$.

\begin{tabular}{l|rr}
\multicolumn{1}{c}{} & \multicolumn{1}{c}{$\begin{array}{c}\text { Annual } \\
\text { Energy Cost }\end{array}$} \\
\cline { 2 - 3 } Modeled - Benchmark Ref. Home & $\$$ & 3,292 \\
Modeled - EGUSA & $\$$ & 957 \\
Modeled - REM/Rate & $\$$ & 365 \\
Measured - Average Bills & $\$$ & 380 \\
\hline
\end{tabular}

As discussed previously, measured energy cost of the occupied homes was significantly lower than modeled costs (using EnergyGauge USA and benchmark procedures). It's also worth noting that most of the incremental costs - 93\% before subsidies - were associated with the solar electric and solar thermal systems (see Table 12). The solar systems, however, are responsible for approximately $50 \%$ of the energy cost savings. If the envelope, HVAC, lighting and appliance savings are considered separately from the solar systems, investments in these systems have a $47 \%$ effective rate of return. 


\section{Conclusions}

RDI and CARB have been very pleased with the utility bills from the Wisdom Way Solar Village homes. The commitment and attention to detail on the part of RDI, the design team, and contractors was impressive, and it’s gratifying to see average energy costs of \$337 per year. Below are discussions of several systems or issues that were very successful, challenging, or merit more investigation.

\subsection{Double Wall System}

RDI found that the double wall system worked quite well for them. While the system is quite labor-intensive, it was a build-able, cost-effective way to dramatically improve the homes' envelopes. One of the reasons double-wall system worked especially well in these homes is that the homes were designed with double-walls in mind. The footprint of all homes is essentially rectangular - with a single box bay in each floor plan. There are no dormers, kneewalls, or variations in wall height on the same floor. During the design phase, the architects were very conscious of simplifying framing.

RDI found that good planning for wall penetrations - especially for appliance venting - is quite important. There were several meetings during construction when solutions for venting needed to be determined on-site. Planning for venting is always important, but with double-walls, mistakes that require moving such penetrations are much more involved. Venting issues were further complicated by accessibility goals of the homes, discussed below.

\subsection{Accessibility}

RDI's goal was to make two of the homes fully accessible and the first floors of all homes "visitable" by people with disabilities. To lower the level of first floor with respect to grade, the floor joists were hung from the sill at the top of the foundation - rather than set upon the sill plate. This change had two important effects: eliminating the band joist and making window wells extremely deep.

The elimination of the band joist - through which venting is traditionally run for basement appliances - meant that water heater vent pipes and dryer exhaust pipes must be run up into the double walls to $90^{\circ}$ turns then to the exterior terminations. This complicated venting - which is very important to plan for in such double wall systems. In several instances, the first floor wall thicknesses were increased (to approximately 15”) to accommodate vent pipes. In other cases, venting could be done behind cabinets or in small chases. These venting challenges were not entirely clear until construction began.

Because of the low level of the first floor, basement windows would have required very deep window wells. The initial cost and ongoing maintenance of these deep wells moved RDI to eliminate basement windows. The elimination of the windows triggered a requirement for basement ventilation in the first four homes (with code changes part-way through construction, ventilation was not required in the later 16 homes). The building department required both air intake and exhaust to the unconditioned basements; this requirement was met with an exhaust fan and passive intake duct. The exhaust fan operated when basement lights were turned on. 
While the goal of having capability to remove pollutants from the basement air is laudable, the effect of this ventilation requirement was the introduction of substantial amounts of moisture into the basements during the summer. CARB and RDI foresaw this, and RDI provided dehumidifiers for these first four homes. The dehumidifiers were intended to be located on shelves so that the condensate could be routed to the washer drain. Homeowner operation of the dehumidifiers, however, proved to be inconsistent. The basement ventilation resulted in very humid basement conditions in some basements and high electricity use from the dehumidifiers.

\subsection{Siding}

As described above, the architects made great efforts to create simple floor plans to limit the framing time and cost associated with the double wall system. This resulted in homes that were basically boxes; to make the homes more aesthetically appealing, the architects used several different siding styles and colors. Most agree that these aesthetics work very well, but the details involved in integrating fiber-cement clapboard, shingle, and panel proved to be more challenging, time-consuming, and expensive than planned. CARB does not have actual increased siding costs, but these could be considered indirect costs related to the double-wall system.

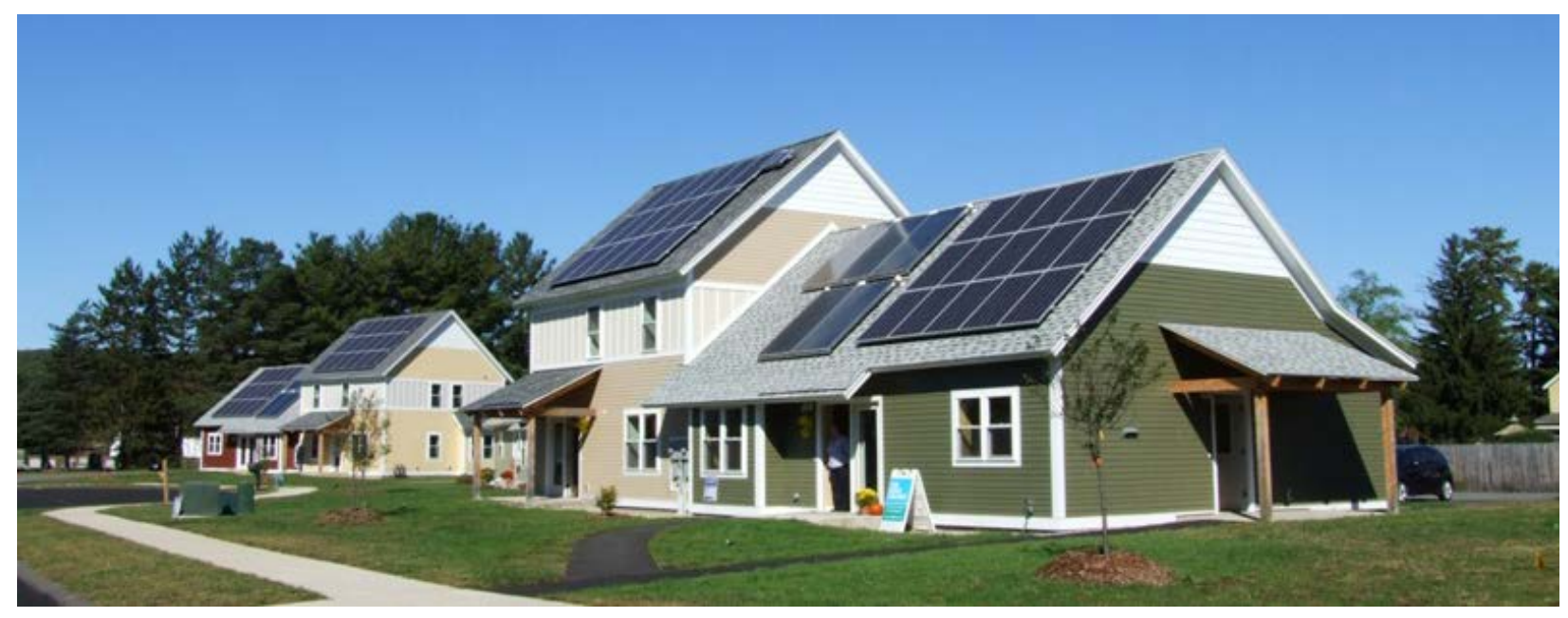

Figure 12. Several completed WWSV homes.

\subsection{Mechanical Plans}

CARB provided mechanical plans for each home plan, with understanding that plans may need to be altered based on plan variations, utility locations, etc. CARB did not always get word of these variations, and some quick decisions needed to be made on site during construction. In two or three homes, this led to solar thermal tanks being located quite far from the auxiliary water heaters. With this configuration, there may be more than one gallon of water in the pipe between the two - leading to reduced solar effectiveness and higher gas use - especially for short hot water draws. This example highlights the importance of up-front planning and quality control.

\subsection{Room Heaters}

RDI was able to save several thousand dollars in each home by installing a single room heater. This is a non-conventional strategy, but CARB performed both short and long-term testing to evaluate the effectiveness of the heating system. Based on the monitoring results - and interviews with occupants - the systems appear to provide adequate comfort with very low gas 
costs. Based on the findings, CARB believes this strategy may offer cost-effective pathways to meet aggressive energy goals and that more detailed investigations are called for. CARB has reported on these results in much more detail in the report "Point-Source Heating Systems in Cold-Climate Homes: Wisdom Way Solar Village” (CARB 2010).

\subsection{Solar Thermal Systems}

As described above, each home has a solar thermal system that can provide most of the energy needed to heat domestic water. From looking at gas bills (also described above), it's clear that during the summer solar provided most (or all) water heating in the homes. In August of 2010, CARB began monitoring performance of one system in some detail. Preliminary results - and many more details on challenges with the solar systems - are in the CARB report: "Advanced Systems Research: Solar Thermal Systems at RDI’s Wisdom Way Solar Village” (CARB 2010).

\section{Acknowledgements}

CARB's work in this project has been funded through the Building America Program, part of the U.S. Department of Energy Building Technologies Program. CARB would like to thank committed people at RDI, their contractors, Austin Design, Joan Rockwell \& Associates, and also WWSV homeowners who participated in evaluation efforts. CARB is also grateful to Western Massachusetts Electric Company and Berkshire Gas for providing utility bill information. 


\section{References}

ASHRAE. 2010. ANSI/ASHRAE Standard 62.2-2010, Ventilation and Acceptable Indoor Air Quality in Low-Rise Residential Buildings. Atlanta: American Society of Heating, Refrigerating and Air Conditioning Engineers, Inc.

Barley, C.D., R. Anderson, R. Hendron, E. Hancock. (2007). A Test Protocol for Room-toRoom Distribution of Outside Air by Residential Ventilation Systems. National Renewable Energy Laboratory, NREL/TP-550-31548. http://www.nrel.gov/buildings/pdfs/31548.pdf. Accessed May 31, 2011.

[CARB] Consortium for Advanced Residential Buildings. (2007). "Completion of Performance Evaluations of Research Houses Targeting at Minimum 40\% Whole House Energy Savings." Task 13.B.2, NREL Task Order KAAX-3-33411-13.

[CARB] Consortium for Advanced Residential Buildings. (2010). "Advanced Systems Research: Solar Thermal Systems at RDI’s Wisdom Way Solar Village.” 2010 Annual Progress Report, Budget Period 3, Attachment OO. Submitted to NETL, December 2010.

[CARB] Consortium for Advanced Residential Buildings. (2010). "Point-Source Heating Systems in Cold-Climate Homes: Wisdom Way Solar Village.” 2010 Annual Progress Report, Budget Period 3, Attachment FF. Submitted to NETL, December 2010.

Hendron, R. (January 2008). Building America Research Benchmark Definition, Updated December 20, 2007. NREL/TP-550-42662. Golden, CO: National Renewable Energy Laboratory.

[Orange] "History for Orange, MA.” 2011. Weather Underground. http://www.wunderground.com/history/airport/KORE/2011/7/12/CustomHistory.html. Accessed July 12, 2011. 


\section{Appendix: Sample Floor Plan}

Following is the floor plan of one duplex from Austin Design, Inc. with mechanical layouts provided by CARB. 


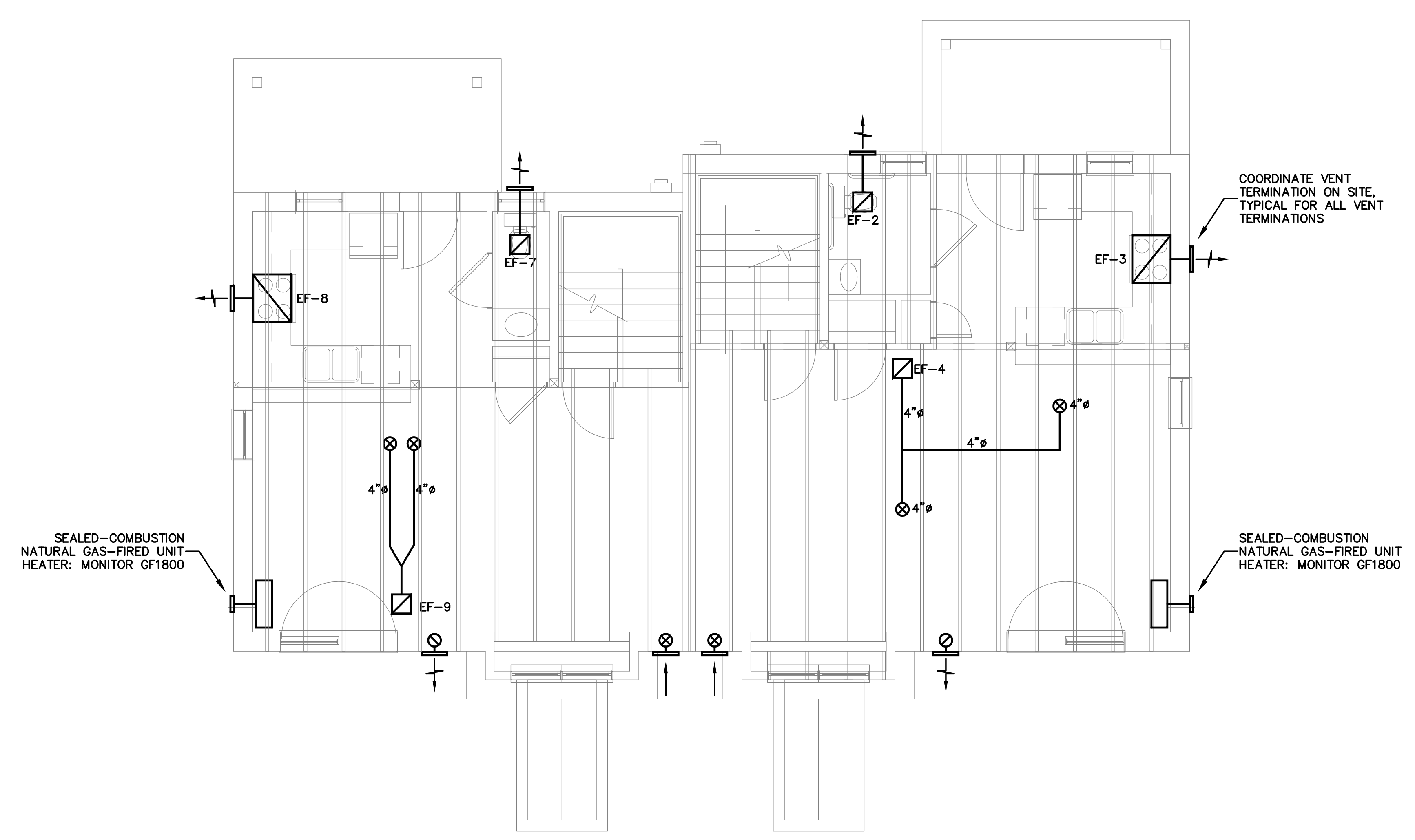

M-101

RDI WISDOM WAY SOLAR VILLAGE - LOT 10

GREENFELD, MA

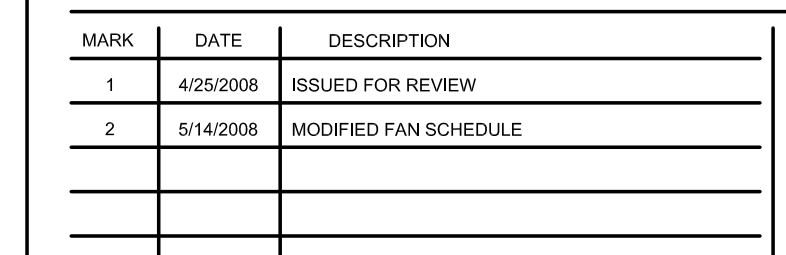

FIRST FLOOR MECHANICAL LAYOUT

Steven Winter Design, Inc.

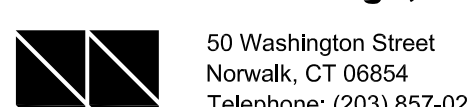




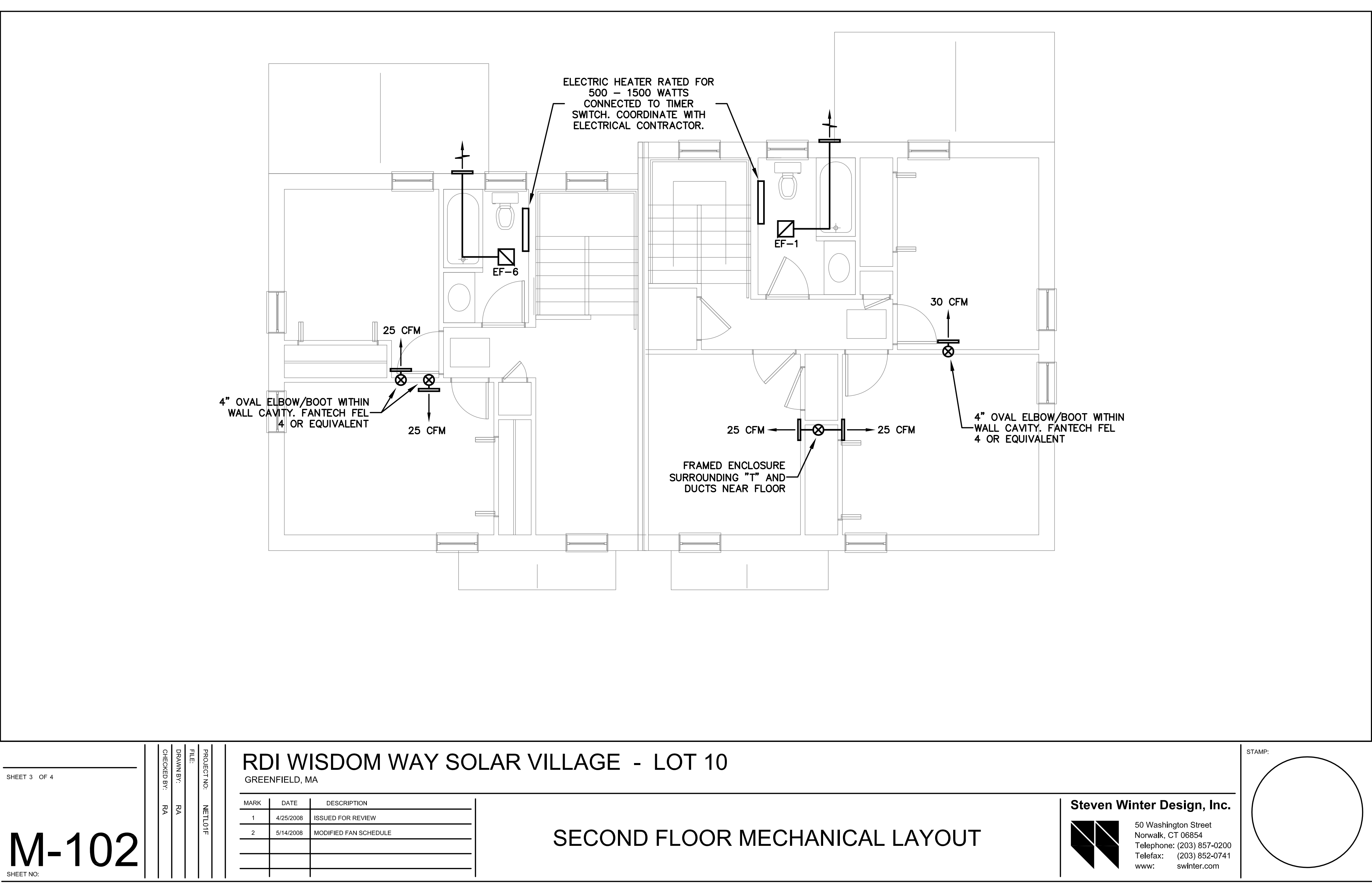

